This document is confidential and is proprietary to the American Chemical Society and its authors. Do not copy or disclose without written permission. If you have received this item in error, notify the sender and delete all copies.

\title{
Design of an Activity-Based Probe for Human Neutrophil Elastase: Implementation of the Lossen Rearrangement to Induce Förster Resonance Energy Transfers
}

\begin{tabular}{|r|l|}
\hline Journal: & Biochemistry \\
\hline Manuscript ID & bi-2017-009066.R2 \\
\hline Manuscript Type: & Article \\
\hline Date Submitted by the Author: & n/a \\
\hline Complete List of Authors: & $\begin{array}{l}\text { Schulz-Fincke, Anna-Christina; University of Bonn, Pharmaceutical Institute } \\
\text { Tikhomirov, Alexander; Gause Instituteof new Antibiotics } \\
\text { Braune, Annett; German Institute of Human Nutrition Potsdam- } \\
\text { Rehbruecke, Gastrointestinal Microbiology } \\
\text { Girbl, Tamara; Queen Mary University of London, William Harvey Research } \\
\text { Institute } \\
\text { Gilberg, Erik; LIMES Program Unit Chemical Biology and Medicinal } \\
\text { Chemistry, Department of Life Science Informatics } \\
\text { Bajorath, Jürgen; University of Bonn, Life Science Informatics, B-IT; } \\
\text { University of Bonn, Department of Life Science Informatics } \\
\text { Blaut, Michael; German Institute of Human Nutrition, Dept. of } \\
\text { Gastrointestinal Microbiology } \\
\text { Nourshargh, Sussan; Queen Mary University of London, William Harvey } \\
\text { Research Institute } \\
\text { Gütschow, Michael; University of Bonn, Pharmaceutical Institute }\end{array}$ \\
\hline
\end{tabular}




\title{
Design of an Activity-Based Probe for Human
}

\section{Neutrophil Elastase: Implementation of the Lossen}

\section{Rearrangement to Induce Förster Resonance Energy}

\section{Transfers}

\author{
Anna-Christina Schulz-Fincke, ${ }^{\S}$ Alexander S. Tikhomirov, ${ }^{\S}{ }^{\dagger}$ Annett Braune, ${ }^{+}$Tamara Girbl, ${ }^{\infty}$ \\ Erik Gilberg, ${ }^{\S, \#}$ Jürgen Bajorath, ${ }^{\#}$ Michael Blaut, ${ }^{\ddagger}$ Sussan Nourshargh, ${ }^{\infty}$ and Michael \\ Gütschow ${ }^{\S}{ }^{*}$
}

${ }^{\S}$ Pharmaceutical Institute, Pharmaceutical Chemistry I, University of Bonn, An der Immenburg 4, 53121 Bonn, Germany

${ }^{\dagger}$ Gause Institute of New Antibiotics, 11 Bolshaya Pirogovskaya Street, Moscow 119021, Russia

$\$$ Department of Gastrointestinal Microbiology, German Institute of Human Nutrition PotsdamRehbruecke, Arthur-Scheunert-Allee 114-116, 14558 Nuthetal, Germany

${ }^{\infty}$ William Harvey Research Institute, Barts and The London School of Medicine and Dentistry, Queen Mary University of London, Charterhouse Square, London EC1M 6BQ, UK

\# Department of Life Science Informatics, B-IT, LIMES Program Unit Chemical Biology and Medicinal Chemistry, University of Bonn, Dahlmannstr. 2, 53113 Bonn, Germany. 


\title{
KEYWORDS
}

Activity-based probes, elastase, enzyme inhibition, FRET, Lossen rearrangement

\begin{abstract}
Human neutrophil elastase is an important regulator of the immune response and plays a role in host defense mechanisms and further physiological processes. The uncontrolled activity of this serine protease may cause severe tissue alterations and impair inflammatory states. The design of an activity-based probe for human neutrophil elastase reported herein relies on a sulfonyloxyphthalimide moiety as a new type of warhead which was linker-connected to a coumarin fluorophore. The inhibitory potency of the activity-based probe was assessed against several serine and cysteine proteases and selectivity for human neutrophil elastase $\left(K_{\mathrm{i}}=6.85\right.$ $\mathrm{nM}$ ) was determined. The adequate fluorescent tag of the probe allowed for the in-gel fluorescence detection of human neutrophil elastase in the low nanomolar range. The coumarin moiety and the anthranilic acid function of the probe, produced in the course of a Lossen rearrangement, were part of two different Förster resonance energy transfers.
\end{abstract}




\section{TABLE OF CONTENT}

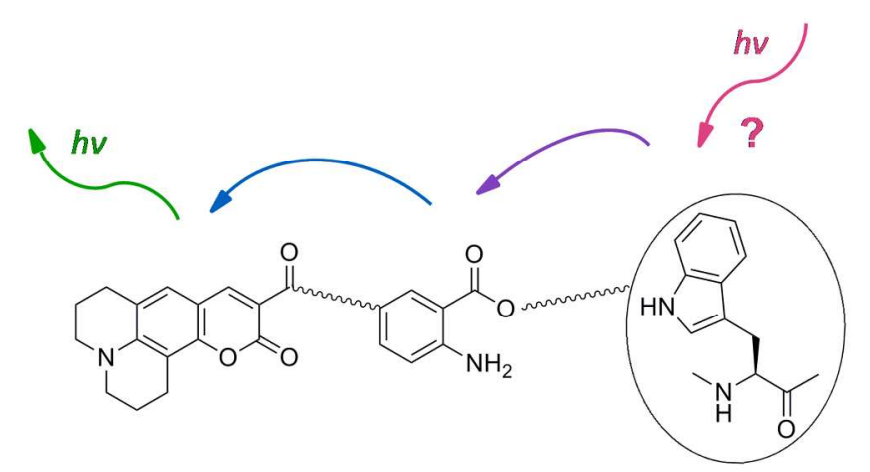




\section{INTRODUCTION}

Human neutrophil elastase (HNE) belongs to the chymotrypsin family of serine proteases and is primarily localized in the azurophilic granules and released upon stimulation of the polymorphonuclear neutrophils. HNE has a shallow S1 pocket resulting in a primary substrate specificity for small aliphatic residues, e.g. of alanine, isoleucine or valine, in the P1 position of the substrate. As a serine protease, HNE cleaves its substrates following an acyl transfer mechanism. ${ }^{1}$ HNE exhibits a broad substrate specificity. It cleaves fibrous elastin, a highly elastic protein in connective tissues, as well as fibronectin, laminin and collagens. Besides these extracellular matrix proteins, HNE degrades a variety of plasma proteins, activates other proteases or deactivates their endogenous inhibitors and liberates growth factors. ${ }^{1}$

HNE participates in host defense against microbial pathogens due to its capability of cleaving outer membrane proteins of Gram-negative bacteria. A fusion of azurophilic granules with vacuoles carrying phagocytosed bacteria leads to the formation of phagolysosomes, the site of pathogen clearance. ${ }^{1}$ In addition to intracellular defense mechanisms, HNE exerts an extracellular antimicrobial activity. It serves as a component of the neutrophil extracellular traps, a network of chromatin and granule proteins, which is actively secreted by neutrophils. ${ }^{1,2}$

In pathophysiological conditions, a deleterious effect may result from the extended tissue destruction catalyzed by HNE. Upon neutrophil activation at inflammatory sites, HNE is abundantly released into the intercellular space, thereby activating proinflammatory mediators and recruiting further neutrophils. Thus, the out-of-balance activity of HNE contributes to the onset and progression of several inflammatory disorders, among them chronic obstructive pulmonary disease, respiratory distress syndrome (ARDS), acute lung injury (ALI), cystic fibrosis and rheumatoid arthritis. ${ }^{1}$ 
Upon neutrophil activation by cytokines, chemoattractants or bacterial lipopolysaccharides, HNE is secreted into the extracellular space, and a fraction of the proteolytically active enzyme remains associated with the outer surface of the plasma membrane of neutrophils. In particular, the lipid leukotriene $\mathrm{B}_{4}\left(\mathrm{LTB}_{4}\right)$ is known to efficiently induce both cell surface presentation of $\mathrm{HNE}$ and HNE release into the environment. The activation of the $\mathrm{LTB}_{4}-\mathrm{HNE}$ axis can promote the cleavage of adhesion molecules and drive remote organ damage. ${ }^{3}$

Potent and selective HNE inhibitors could prove therapeutically useful to reduce or treat HNEdependent disorders. Sivelestat has reached the market for the treatment of ALI/ARDS in Japan and South Korea. Sivelestat has been reported to interact with HNE in a substrate-like manner. The drug's ester bond undergoes an enzymatic cleavage, a pivaloyl residue is transferred to the active site serine and the resulting acyl enzyme is proposed to undergo hydrolysis. ${ }^{4}$ Other inhibitors of HNE comprise, e.g. peptidic trifluoromethyl ketones and phosphonates, ${ }^{5} 4 H-3,1-$ benzoxazin-ones, ${ }^{6}$ azetidine-2,4-diones and saccharines, ${ }^{7}$ kojic acid derivatives, ${ }^{8}$ cyanobacterial cyclic peptides and depsipeptides. ${ }^{9}$ Several classes of structurally-diverse heterocyclic HNE inhibitors, including 2-pyridones (e.g. AZD9668) and 3,4-dihydropyrimidin-2(1H)-ones (e.g. BAY-678), have been reported. ${ }^{1}$

Due to the protease's involvement in several diseases and its role as a pathogenic mediator in pulmonary disorders, HNE inhibition has become an important pharmaceutical option. Aside its role as a drug target, HNE-generated fragments of elastin and, recently, HNE itself have been described to be biomarkers for certain elastase-related conditions. ${ }^{10}$ Moreover, activity-based probes (ABPs) for HNE are considered to be valuable for the detection and detailed investigation of this protease. In general, ABPs for serine proteases have emerged as powerful tools in life science. ${ }^{11}$ ABPs enlarge the repertoire of methods, of which Western blotting is particularly 
important, for detecting a certain protein. ABPs are active site-directed compounds and can selectively visualize the enzyme of interest in complex biological samples. Different electrophilic structures have been employed as warheads for the assembly of ABPs for HNE, i.e. isocoumarins, ${ }^{12}$ sulfonyl fluorides, ${ }^{13}$ azetidine-2,4-diones,${ }^{14}$ and phosphonates. ${ }^{15}$

Förster resonance energy transfer (FRET) constitutes a powerful tool for the visualization of protein activities. ${ }^{16}$ In the present study, we conducted the design, synthesis, photophysical and biological evaluation of a fluorescent ABP for HNE equipped with a sulfonyloxyphthalimide moiety. We demonstrate that this warhead is capable to trigger appropriate FRET signals to study the enzyme-probe interaction.

\section{MATERIALS AND METHODS}

General. Melting points were determined on a Büchi 50 oil bath apparatus. Thin layer chromatography was performed using Merck aluminium sheets coated with silica gel $60 \mathrm{~F}_{254}$. NMR spectra were recorded using Bruker Avance III-600 MHz and Bruker Avance DRX-500 MHz instruments. LC-DAD chromatograms and ESI-MS spectra were recorded on an Agilent 1100 HPLC system with an Applied Biosystems API-2000 mass spectrometer. HRMS was performed on a microTOF-Q mass spectrometer (Bruker, Köln, Germany) with ESI-source coupled with a HPLC Dionex Ultimate 3000 (Thermo Scientific, Braunschweig, Germany) using a EC50/2 Nucleodur C18 Gracity $3 \mu \mathrm{m}$ column (Macherey-Nagel, Düren, Germany). A volume of one $\mu \mathrm{L}$ of a sample solution $(1.0 \mathrm{mg} / \mathrm{mL})$ was injected. Mobile phase was a mixture of $2 \mathrm{mM}$ aqueous ammonium acetate solution and acetonitrile. Elution was performed from 90:10 up to 0:100 in $9 \mathrm{~min}, 0: 100$ for $5 \mathrm{~min}$. Elemental analysis was performed with a vario MICRO 
apparatus. Absorption spectra were recorded on Varian Cary 50 Bio, emission spectra on a Monaco Safas spectrofluorometer flx.

General Enzymatic Methods. Enzyme activities were assayed spectrophotometrically on a Varian Cary 50 Bio or on a Varian Cary 100 Bio device, respectively. Fluorometric assays were monitored on a FLUOstar Optima plate reader from BMG Labtech (Offenburg, Germany) in 96 well plates. FRET kinetics was monitored on a Monaco Safas spectrofluorometer flx. HNE, PPE, human thrombin and human cathepsin B were obtained from Calbiochem (Darmstadt, Germany), bovine chymotrypsin, bovine factor Xa and bovine trypsin from Sigma Aldrich, Germany, and human cathepsin L from Enzo Life Science (Lörrach, Germany). MeOSuc-Ala-Ala-Pro-ValpNA was purchased from Calbiochem (Darmstadt, Germany), Suc-Ala-Ala-Pro-Phe-pNA, ZGly-Gly-Arg-AMC, Boc-Ile-Glu-Gly-Arg-AMC, Suc-Ala-Ala-Pro-Arg-pNA, Z-Arg-Arg-pNA, Z-Phe-Arg-pNA were from Bachem (Bubendorf, Switzerland). Reactions were monitored for 60 min unless stated otherwise. Experiments were performed in duplicate with five different inhibitor concentrations.

Enzyme Inhibition Assays. Human Neutrophil Elastase. ${ }^{17}$ Assay buffer was $50 \mathrm{mM}$ sodium phosphate buffer containing $500 \mathrm{mM} \mathrm{NaCl}, \mathrm{pH}$ 7.8. An enzyme stock solution of $50 \mu \mathrm{g} / \mathrm{mL}$ was prepared in $100 \mathrm{mM}$ sodium acetate buffer, $\mathrm{pH}$ 5.5. An aliquot was kept at $0^{\circ} \mathrm{C}$ and diluted with assay buffer directly before the measurement. A $50 \mathrm{mM}$ stock solution of the chromogenic substrate MeOSuc-Ala-Ala-Pro-Val-pNA in DMSO was diluted with assay buffer containing $10 \%$ DMSO. The final concentrations were as follows: substrate, $100 \mu \mathrm{M}\left(=1.85 \times K_{\mathrm{m}}\right)$; DMSO, 1.5\%; HNE, $35 \mathrm{ng} / \mathrm{mL}$. Into a cuvette containing $890 \mu \mathrm{L}$ assay buffer, $10 \mu \mathrm{L}$ inhibitor solution in DMSO and $50 \mu \mathrm{L}$ substrate solution were added and thoroughly mixed. The reaction was performed at $25^{\circ} \mathrm{C}$, initiated by adding $50 \mu \mathrm{L}$ of the enzyme solution and monitored at $405 \mathrm{~nm}$. 
Porcine Pancreatic Elastase. Assay buffer was $50 \mathrm{mM}$ sodium phosphate buffer containing $500 \mathrm{mM} \mathrm{NaCl}, \mathrm{pH}$ 7.8. An enzyme stock solution of $100 \mathrm{U} / \mathrm{mL}$ was prepared in $100 \mathrm{mM}$ sodium acetate buffer, $\mathrm{pH}$ 5.5. An aliquot was kept at $0^{\circ} \mathrm{C}$ and diluted with assay buffer directly before the measurement. A $50 \mathrm{mM}$ stock solution of the chromogenic substrate MeOSuc-Ala-Ala-ProVal-pNA was prepared in DMSO and diluted with assay buffer containing 10\% DMSO. In accordance to literature, ${ }^{18}$ a $K_{\mathrm{m}}$ value greater than $1000 \mu \mathrm{M}$ was determined with 18 different substrate concentrations in triplicate measurements. For the inhibition assay, the final concentrations were as follows: substrate, $100 \mu \mathrm{M}\left(<<K_{\mathrm{m}}\right)$; DMSO, 1.5\%; PPE, $0.01 \mathrm{U} / \mathrm{mL}$. Into a cuvette containing $890 \mu \mathrm{L}$ assay buffer, $10 \mu \mathrm{L}$ inhibitor solution in DMSO and $50 \mu \mathrm{L}$ substrate solution were added and thoroughly mixed. The reaction was performed at $25^{\circ} \mathrm{C}$, initiated by adding $50 \mu \mathrm{L}$ of the enzyme solution and monitored at $405 \mathrm{~nm}$.

Bovine Chymotrypsin. ${ }^{19}$ Assay buffer was $20 \mathrm{mM}$ Tris- $\mathrm{HCl}$ buffer containing $150 \mathrm{mM} \mathrm{NaCl}$, $\mathrm{pH}$ 8.4. An enzyme stock solution of $1 \mathrm{mg} / \mathrm{mL}$ was prepared in $1 \mathrm{mM}$ aqueous $\mathrm{HCl}$, diluted with assay buffer and kept at $0^{\circ} \mathrm{C}$. A $40 \mathrm{mM}$ stock solution of chromogenic substrate Suc-Ala-AlaPro-Phe-pNA was prepared in DMSO and diluted with assay buffer containing 10\% DMSO. The final concentrations were as follows: substrate, $200 \mu \mathrm{M}\left(=2.68 \times K_{\mathrm{m}}\right) ;{ }^{20} \mathrm{DMSO}, 6 \%$; chymotrypsin, $50 \mathrm{ng} / \mathrm{mL}$. Into a cuvette containing $845 \mu \mathrm{L}$ assay buffer, $55 \mu \mathrm{L}$ inhibitor solution in DMSO and $50 \mu \mathrm{L} 4 \mathrm{mM}$ substrate solution were added and thoroughly mixed. The reaction was performed at $25^{\circ} \mathrm{C}$, initiated by adding $50 \mu \mathrm{L}$ of the enzyme solution and monitored at 405 $\mathrm{nm}$.

Human Thrombin. ${ }^{21}$ Assay buffer was $50 \mathrm{mM}$ Tris- $\mathrm{HCl}$ containing $150 \mathrm{mM} \mathrm{NaCl}, \mathrm{pH}$ 8.0. The enzyme stock solution $(10000 \mathrm{U} / \mathrm{mL})$ was prepared in water, diluted with assay buffer and kept at $0^{\circ} \mathrm{C}$. A $10 \mathrm{mM}$ stock solution of the fluorogenic substrate Z-Gly-Gly-Arg-AMC in 
DMSO was diluted with assay buffer. The final concentrations were as follows: substrate, $40 \mu \mathrm{M}$ $\left(=1.00 \times K_{\mathrm{m}}\right) ; \mathrm{DMSO}, 6 \%$; thrombin, $1.5 \mathrm{U} / \mathrm{mL}$. Into each well containing $173.8 \mu \mathrm{L}$ assay buffer, $11.2 \mu \mathrm{L}$ inhibitor solution in DMSO and $10 \mu \mathrm{L}$ substrate solution were added and thoroughly mixed. The reaction was performed at $25^{\circ} \mathrm{C}$, initiated by adding $5 \mu \mathrm{L}$ of the enzyme solution and monitored with an excitation wavelength of $340 \mathrm{~nm}$ and emission wavelength of $460 \mathrm{~nm}$.

Bovine Factor Xa. ${ }^{22}$ Assay buffer was $50 \mathrm{mM}$ Tris-HCl containing $100 \mathrm{mM} \mathrm{NaCl}$ and $10 \mathrm{mM}$ $\mathrm{CaCl}_{2}, \mathrm{pH}$ 8.0. The enzyme stock solution $(1 \mathrm{U} / \mu \mathrm{L})$ was prepared in water, diluted with assay buffer (1:50) and kept at $0^{\circ} \mathrm{C}$. A $20 \mathrm{mM}$ stock solution of fluorogenic substrate Boc-Ile-Glu-GlyArg-AMC $\cdot \mathrm{AcOH}$ in DMSO was diluted with assay buffer. The final concentrations were as follows: substrate, $100 \mu \mathrm{M}\left(=1.69 \times K_{\mathrm{m}}\right)$; DMSO, $6 \%$; factor Xa, $0.5 \mathrm{U} / \mathrm{mL}$. Into each well containing $174 \mu \mathrm{L}$ assay buffer, $11 \mu \mathrm{L}$ inhibitor solution in DMSO and $10 \mu \mathrm{L}$ substrate solution were added and thoroughly mixed. The reaction was performed at $25^{\circ} \mathrm{C}$, initiated by adding 5 $\mu \mathrm{L}$ of the enzyme solution and monitored over $45 \mathrm{~min}$ with an excitation wavelength of $340 \mathrm{~nm}$ and emission wavelength of $460 \mathrm{~nm}$.

Bovine Trypsin. ${ }^{23}$ Assay buffer was $20 \mathrm{mM}$ Tris- $\mathrm{HCl}$ containing $150 \mathrm{mM} \mathrm{NaCl}, \mathrm{pH}$ 8.4. The trypsin stock solution $(10 \mu \mathrm{g} / \mathrm{mL})$ was prepared in $1 \mathrm{mM} \mathrm{HCl}$, diluted with assay buffer and kept at $0^{\circ} \mathrm{C}$. A $40 \mathrm{mM}$ stock solution of the chromogenic substrate Suc-Ala-Ala-Pro-Arg-pNA in DMSO was diluted with assay buffer. The final concentrations were as follows: substrate, 200 $\mu \mathrm{M}\left(=2.70 \times K_{\mathrm{m}}\right) ; \mathrm{DMSO}, 6 \%$; bovine trypsin, $40 \mathrm{ng} / \mathrm{mL}$. Into a cuvette containing $845 \mu \mathrm{L}$ assay buffer, $50 \mu \mathrm{L} 4 \mathrm{mM}$ substrate solution and $55 \mu \mathrm{L}$ inhibitor solution in DMSO were added and thoroughly mixed. The reaction was performed at $25^{\circ} \mathrm{C}$, initiated by adding $50 \mu \mathrm{L}$ of the enzyme solution and monitored at $405 \mathrm{~nm}$. 
Human Cathepsin B. ${ }^{24}$ Assay buffer was $100 \mathrm{mM}$ sodium phosphate buffer, containing 100 $\mathrm{mM} \mathrm{NaCl}, 5 \mathrm{mM}$ EDTA and $0.01 \%$ Brij 35, $\mathrm{pH}$ 6.0. An enzyme stock solution of $1.81 \mathrm{mg} / \mathrm{mL}$ in $20 \mathrm{mM}$ sodium acetate buffer containing $1 \mathrm{mM}$ EDTA, $\mathrm{pH}$ 5.0, was diluted 1:500 with assay buffer containing $5 \mathrm{mM}$ DTT and incubated for $30 \mathrm{~min}$ at $37^{\circ} \mathrm{C}$ and kept at $0^{\circ} \mathrm{C}$. A $100 \mathrm{mM}$ stock solution of the chromogenic substrate Z-Arg-Arg-pNA was prepared with DMSO. The final concentrations were as follows: substrate, $500 \mu \mathrm{M}\left(=0.45 \times K_{\mathrm{m}}\right)$; DMSO, $2 \%$; cathepsin B, $72 \mathrm{ng} / \mathrm{mL}$. Into a cuvette containing $960 \mu \mathrm{L}$ assay buffer, $15 \mu \mathrm{L}$ inhibitor solution in DMSO and $5 \mu \mathrm{L}$ of the substrate solution were added and thoroughly mixed. The reaction was performed at $37{ }^{\circ} \mathrm{C}$, initiated by adding $20 \mu \mathrm{L}$ of the enzyme solution and monitored at $405 \mathrm{~nm}$.

Human Cathepsin L. ${ }^{24}$ Assay buffer was $100 \mathrm{mM}$ sodium phosphate buffer containing 100 $\mathrm{mM} \mathrm{NaCl}, 5 \mathrm{mM}$ EDTA and $0.01 \%$ Brij 35, $\mathrm{pH}$ 6.0. An enzyme stock solution of $135 \mu \mathrm{g} / \mathrm{mL}$ in $20 \mathrm{mM}$ malonate buffer containing $400 \mathrm{mM} \mathrm{NaCl}$ and $1 \mathrm{mM}$ EDTA, $\mathrm{pH}$ 5.5, was diluted 1:100 with assay buffer containing $5 \mathrm{mM} \mathrm{DTT}$, incubated for $30 \mathrm{~min}$ at $37^{\circ} \mathrm{C}$ and kept at $0^{\circ} \mathrm{C}$. A 10 mM stock solution of the chromogenic substrate Z-Phe-Arg-pNA was prepared with DMSO. The final concentrations were as follows: substrate, $100 \mu \mathrm{M}\left(=5.88 \times K_{\mathrm{m}}\right)$; DMSO, $2 \%$; cathepsin L, $54 \mathrm{ng} / \mathrm{mL}$. Into a cuvette containing $940 \mu \mathrm{L}$ assay buffer, $10 \mu \mathrm{L}$ inhibitor solution in DMSO and $10 \mu \mathrm{L}$ of the substrate solution were added and thoroughly mixed. The reaction was performed at $37^{\circ} \mathrm{C}$, initiated by adding $20 \mu \mathrm{L}$ of the enzyme solution and monitored at $405 \mathrm{~nm}$.

FRET Kinetics with Porcine Pancreatic Elastase. $\lambda_{e x} 320 \mathrm{~nm}$ FRET. The reactions of probe $\mathbf{8}$ with PPE were followed by monitoring the fluorescence-resonance energy transfer from the anthranilic acid fluorophore to the coumarin 343 by setting the excitation wavelength for anthranilic acid at $\lambda_{\mathrm{ex}}=320 \mathrm{~nm}$ and the emission wavelength of coumarin 343 at $\lambda_{\mathrm{em}}=492 \mathrm{~nm}$. A photomultiplier tube (PMT) value of $300 \mathrm{~V}$ was adjusted. The experiments were performed at 
$25^{\circ} \mathrm{C}$ for $60 \mathrm{~min}$. Buffer was $50 \mathrm{mM}$ sodium phosphate buffer and $500 \mathrm{mM} \mathrm{NaCl}, \mathrm{pH}$ 7.8. A PPE solution was prepared in $10 \mathrm{mM}$ sodium acetate buffer, $\mathrm{pH}$ 5.5. Probe 8 was dissolved DMSO. The final concentration of PPE was $3.1 \mathrm{U} / \mathrm{mL}$ and the final concentration of DMSO was $1.5 \%$. Buffer, DMSO and probe $\mathbf{8}$ were placed in a cuvette. It was thoroughly mixed and the reaction was initiated by adding the enzyme. Experiments were performed in duplicate with five different inhibitor concentrations.

$\lambda_{\text {ex }} 285 \mathrm{~nm}$ FRET. The experiments were performed as described above with the following exception. The reactions of 8 with PPE were followed over 60 min or 8 hours by monitoring a possible FRET from a tryptophan fluorophore of PPE to the coumarin 343 by setting the excitation wavelength for tryptophan at $\lambda_{\mathrm{ex}}=285 \mathrm{~nm}$ and the emission wavelength of coumarin 343 at $\lambda_{\mathrm{em}}=492 \mathrm{~nm}$.

\section{Detection of Human Neutrophil Elastase with the Activity-based Probe 8. Estimation of} the Detection Limit of the Probe. A $200 \mu \mathrm{M}$ solution of the activity-based probe $\mathbf{8}$ was prepared in DMSO. A HNE solution of $267 \mu \mathrm{g} / \mathrm{mL}$ was prepared in $100 \mathrm{mM}$ sodium acetate buffer, $\mathrm{pH}$ 5.5. Elastase assay buffer ( $50 \mathrm{mM}$ sodium phosphate buffer containing $500 \mathrm{mM} \mathrm{NaCl}, \mathrm{pH} 7.8$ ) was used to prepare mixtures of a total volume of $40 \mu \mathrm{L}$ containing $2.5 \mu \mathrm{M}$ of probe $8,2.5 \%$ DMSO and different concentration of HNE (11 ng/ $\mu \mathrm{L}, 18 \mathrm{ng} / \mu \mathrm{L}, 25 \mathrm{ng} / \mu \mathrm{L}, 33 \mathrm{ng} / \mu \mathrm{L}, 40 \mathrm{ng} / \mu \mathrm{L})$ (Fig. 5A). These mixtures were incubated at $25^{\circ} \mathrm{C}$ for $20 \mathrm{~min}$. To $18 \mu \mathrm{L}$ of each mixture, $6 \mu \mathrm{L}$ of reducing $4 \times$ Roti-Load 1 buffer (Roth, Karlsruhe, Germany) was added followed by heating at $95{ }^{\circ} \mathrm{C}$ for $5 \mathrm{~min}$. After centrifugation $(14,000 \times \mathrm{g}, 5 \mathrm{~min})$, volumes of $20 \mu \mathrm{L}$ were loaded and proteins were separated by SDS-PAGE. Gels (13\%) were run in Tris/glycine/SDS buffer (Tris 25 $\mathrm{mM}$, glycine $192 \mathrm{mM}$, SDS 0.1\%). The enzyme was visualized by in-gel fluorescence detection using a Typhoon Trio scanner (GE Healthcare) and applying a setting which is most adequate for 
the coumarin fluorophore, i.e. the 488-nm blue laser and an emission 520-nm band-pass filter (520 BP 40). A PMT value of $600 \mathrm{~V}$ and a pixel size scanning resolution of $100 \mu \mathrm{m}$ were adjusted. Prestained marker proteins (PageRuler Plus Prestained Protein Ladder, ThermoFisher Scientific, Waltham, MA) served as standards.

Competition Experiment. A $400 \mu \mathrm{M}$ solution of sivelestat (Sigma Aldrich, Germany) was prepared in DMSO. Two mixtures of a total volume of $39.5 \mu \mathrm{L}$ containing HNE in both samples in the presence and absence of sivelestat in one sample were prepared in elastase assay buffer and incubated at $25^{\circ} \mathrm{C}$ for $5 \mathrm{~min}$. A volume of $0.5 \mu \mathrm{L}$ of probe 8 was added to both samples to reach the following concentrations, $2.5 \mu \mathrm{M}$ of probe $8,2.5 \% \mathrm{DMSO}, 40 \mathrm{ng} / \mu \mathrm{L}$ of $\mathrm{HNE}$ and 5.0 $\mu \mathrm{M}$ of sivelestat. These mixtures were incubated at $25^{\circ} \mathrm{C}$ for $20 \mathrm{~min}$. SDS-PAGE and in-gel fluorescence detection (Fig. 5B) were performed as described above.

Survey of the Probe's Selectivity. Lysate from human embryonic kidney (HEK) 293 cells was received as described. ${ }^{25}$ Four mixtures were prepared in elastase assay buffer, all containing probe 8. A volume of $4.9 \mu \mathrm{L}$ of HEK cell lysate, or $6.0 \mu \mathrm{L}$ of HNE (twice), or $4.9 \mu \mathrm{L}$ HEK cell lysate spiked with $6.0 \mu \mathrm{L}$ of $\mathrm{HNE}$ were added. The mixtures were incubated at $25^{\circ} \mathrm{C}$ for $20 \mathrm{~min}$. After incubation, $4.9 \mu \mathrm{L}$ of HEK cell lysate was added to one HNE sample. In the final volume of $40 \mu \mathrm{L}$, the mixtures contained $2.5 \mu \mathrm{M}$ of probe $8,2.5 \%$ DMSO, $40 \mathrm{ng} / \mu \mathrm{L}$ of $\mathrm{HNE}$ and 0.60 $\mu \mathrm{g} / \mu \mathrm{L}$ of HEK cell lysate. SDS-PAGE and in-gel fluorescence detection (Fig. 5C) were performed as described above.

Detection of endogenous HNE. Human granulocytes were isolated from peripheral blood of healthy donors using density gradient centrifugation (Histopaque, Sigma Aldrich). For the preparation of the cell lysates, purified granulocytes (40 mio cells) were lysed in $100 \mu \mathrm{L}$ of lysis buffer (1\% Triton X-100 in phosphate buffer saline, $\mathrm{pH} 7.4)$. Cell debris was removed by 
centrifugation $(12,000 \mathrm{~g}, 10 \mathrm{~min})$. Two mixtures of a total volume of $19.75 \mu \mathrm{L}$ containing cell lysate in both samples in the presence and absence of sivelestat were prepared in elastase assay buffer and incubated at $25^{\circ} \mathrm{C}$ for $5 \mathrm{~min}$. A volume of $0.25 \mu \mathrm{L}$ of probe 8 was added to both samples to obtain the following concentrations, $2.5 \mu \mathrm{M}$ of probe $8,2.5 \%$ DMSO, lysate of 6.12 mio cells and $5.0 \mu \mathrm{M}$ of sivelestat. The mixtures were incubated at $25{ }^{\circ} \mathrm{C}$ for $20 \mathrm{~min}$. SDSPAGE and in-gel fluorescence detection (Fig. 6) were performed as described above.

Colloidal Coomassie G-250 Staining. Proteins were stained over night with PageBlue Protein Staining Solution (ThermoFisher Scientific, Waltham, MA). Gels were captured with a G:BOX F3 Gel Documentation System (Syngene, Cambridge, UK) using a visible light converter screen with the UV transilluminator (Figures 5D and 6B).

\section{RESULTS AND DISCUSSION}

Sulfonyloxyphthalimides have been reported as efficient inactivators for HNE and other serine proteases. ${ }^{26-28}$ According to the mechanism depicted in Scheme $1,{ }^{26}$ the protease-inhibitor interaction involves a nucleophilic attack of the active-site serine residue at the carbonyl carbon leading to an opening of the heterocyclic ring and a subsequent Lossen rearrangement of the $O$ sulfonyl hydroxamic acid intermediate. ${ }^{26,29,30}$ If the resulting isocyanate is trapped by water, the acyl enzyme undergoes slow hydrolysis and the enzymatic activity might be recovered. The isocyanate can alternatively react with a second, adjacent nucleophile from the protein matrix, e.g. with His-57 of HNE. In fact, the efficacy of such enzyme-activated inhibitors relies on the initially formed acyl enzyme, which keeps the isocyanate tethered at the active site and facilitates a second covalent attachment, leading to irreversible inactivation. This Lossen-based reactivity of low-molecular weight compounds bearing the cyclic $\mathrm{CO}-\mathrm{N}\left(\mathrm{OSO}_{2} \mathrm{Alk}\right)-\mathrm{CO}$ motif towards 
serine proteases has also been shown for succinimides, ${ }^{31,32}$ dihydrouracils, ${ }^{33}$ and related heterocycles. ${ }^{29}$ The mechanism of inactivation has been established by ${ }^{13} \mathrm{C}$ NMR studies, ${ }^{31}$ and fluorescence spectroscopy. ${ }^{26}$

Scheme 1. Interaction between Sulfonyloxyphthalimides and Serine Proteases

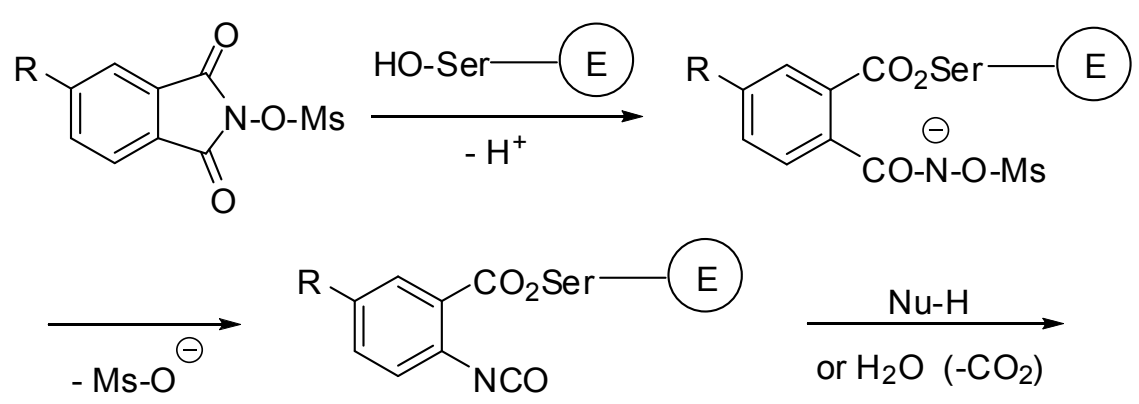<smiles>[R]c1ccc(NC(N)=O)c(C(=O)O[Se]c2ccccc2)c1</smiles>

or<smiles>[R]c1ccc(N)c(C(=O)O[Ga]c2ccccc2)c1</smiles>

For the design of a new type of activity-based probes for HNE, we considered the formation of anthranilic acid derivatives (Scheme 1) in the course of the enzyme-inhibitor interaction. In order to devise a possible FRET sequence from the protein's tryptophan residues via anthranilic acid to a suitable fluorescent reporter, we decided to incorporate coumarin 343 into the ABP for HNE. Coumarins with donor groups at the position 7 , such as coumarin 343 , represent a widely used 
class of fluorescent dyes. A small molecular size, high fluorescence quantum yields and large Stokes shifts, as well as chemical and enzymatic stability are their favored properties. ${ }^{25,34}$ We aimed at synthesizing a small series of linker-connected $N$-(mesyloxy)phthalimides (Scheme 2). The nitro-substituted $N$-hydroxyphthalimide $\mathbf{1}$ was chosen as the starting compound whose nitro group was reduced using $\mathrm{Pd} / \mathrm{C}$ to afford compound 2 . This was converted into a sodium salt with $\mathrm{NaHCO}_{3}$ and immediately reacted with methanesulfonyl chloride to obtain 3 . ${ }^{35}$ A strong electrophile was required for a chemical modification of the aromatic amino group of $\mathbf{3}$. After several unsuccessful attempts, the conversion of $\mathbf{3}$ was achieved with 4-nitrophenyl chloroformate. The resulting active carbamate $\mathbf{4}$ turned out to be readily suitable for the formation of a urea bridge to introduce different linker structures by a subsequent in situ coupling of $\mathbf{4}$ with various mono-Boc-protected diamines. Compounds 5a-d either contain alkylidene or polyethylene glycol (PEG) linkers. These four intermediates were enzymatically evaluated and the most promising PEG derivative 5d was selected for the generation of the final ABP. Removal of the Boc protecting group of $\mathbf{5 d}$ under acidic conditions yielded $\mathbf{6}$. This salt was coupled with coumarin 343 (7) in a HATU-promoted reaction to give the final probe 8 with coumarin 343 as fluorescence tag. 
Scheme 2. Synthesis of Compound $\mathbf{8}^{\mathrm{a}}$<smiles>CC(C)C</smiles><smiles></smiles><smiles>CON1C(=O)c2ccc(N)cc2C1=O</smiles><smiles>CC(C)(C)OC(=O)NNC(=O)Nc1ccc2c(c1)C(=O)N(OC(C)(C)C)C2=O</smiles>

5a $\mathrm{X}=\mathrm{CH}_{2} \mathrm{CH}_{2}$

5b X $=\mathrm{CH}_{2} \mathrm{CH}_{2} \mathrm{CH}_{2} \mathrm{CH}_{2} \mathrm{CH}_{2}$

5c $\mathrm{X}=\mathrm{CH}_{2} \mathrm{CH}_{2} \mathrm{OCH}_{2} \mathrm{CH}_{2}$

5d $\mathrm{X}=\mathrm{CH}_{2} \mathrm{CH}_{2} \mathrm{OCH}_{2} \mathrm{CH}_{2} \mathrm{OCH}_{2} \mathrm{CH}_{2}$<smiles>[Y]ON1C(=O)c2ccc(NC(=O)NCCOCCOCCN)cc2C1=O</smiles><smiles></smiles>

${ }^{\mathrm{a}}$ Reactions and conditions: (a) $\mathrm{H}_{2}, \mathrm{Pd} / \mathrm{C}, \mathrm{CH}_{3} \mathrm{OH}$, rt; (b) $\mathrm{MsCl}, \mathrm{NaHCO}_{3}, \mathrm{H}_{2} \mathrm{O}, 0-5{ }^{\circ} \mathrm{C}$; (c) 4 nitrophenyl chloroformate, THF, rt; (d) amine: Boc-NH-X-NH 2 , DIPEA, rt; (e) 4N HCl in dioxane, $\mathrm{CH}_{2} \mathrm{Cl}_{2}, \mathrm{rt}, 2$ h; (f) coumarin 343 (7), HATU, DIPEA, DMF, rt. 
Compound $\mathbf{8}$ was investigated as an inhibitor of HNE by means of a spectroscopic assay with the chromogenic substrate MeOSuc-Ala-Ala-Pro-Val-pNA (Table 1). Additionally, an estimation of the bioactivity of the Boc-protected building blocks 5a-d was carried out. These compounds showed time-dependent inhibition and the progress curves were analyzed with the slow-binding equation, implementing a distinct steady-state rate. From the first-order rate constants and the steady-rate rates, second-order rate constants for the formation of enzyme-inhibitor complexes, $k_{\text {on }}$, and $K_{\mathrm{i}}$ values, respectively, were obtained. The corresponding analysis for the HNE inhibition by probe $\mathbf{8}$ is depicted in Figure 1. The first-order rate constants for the decay of the enzyme-inhibitor complexes, $k_{\text {off, }}$ were calculated from $k_{\text {on }}$ and $K_{\mathrm{i}}$ values (Table 1$)$. The kinetic parameters of the HNE inhibition by the five compounds do not differ much. From the $k_{\text {off }}$ values, half-lives for the enzyme-inhibitor complexes between $56 \mathrm{~min}(\mathbf{5 d})$ and $177 \mathrm{~min}(\mathbf{5 b})$ were obtained. The $K_{\mathrm{i}}$ values were in the single-digit nanomolar range. As noted above, building block 5d bearing a PEG linker with two oxygen atoms (PEG2) was selected as the precursor for the final ABP (8) because of similar enzyme-inhibiting activities of 5a-d, and the envisaged improved water solubility of a PEG2-containing ABP. The exchange of the Boc-protecting group (in 5d) by the coumarin 343 moiety (in 8) did not result in a loss of inhibitory potency. 
Table 1. Inhibition of HNE by Compounds $\mathbf{5 a - d}$ and $\mathbf{8}^{\mathrm{a}}$

\begin{tabular}{cccc}
\hline Compound & $K_{\mathrm{i}}(\mathrm{nM})$ & $k_{\mathrm{on}}\left(10^{4} \mathrm{M}^{-1} \mathrm{~s}^{-1}\right)$ & $k_{\mathrm{off}}=K_{\mathrm{i}} k_{\mathrm{on}}\left(10^{-4} \mathrm{~s}^{-1}\right)$ \\
\hline $\mathbf{5 a}$ & $6.83 \pm 2.47$ & $1.06 \pm 0.15$ & 0.726 \\
$\mathbf{5 b}$ & $4.39 \pm 1.63$ & $1.49 \pm 0.20$ & 0.654 \\
$\mathbf{5 c}$ & $6.81 \pm 1.77$ & $1.44 \pm 0.57$ & 0.981 \\
$\mathbf{5 d}$ & $5.26 \pm 1.00$ & $3.91 \pm 0.58$ & 2.06 \\
$\mathbf{8}$ & $6.85 \pm 0.39$ & $2.37 \pm 0.15$ & 1.62 \\
\hline
\end{tabular}

${ }^{a}$ Enzymatic activity was determined with five different inhibitor concentrations, [I], in duplicate measurements. Progress curves were analyzed using the slow-binding equation $[\mathrm{P}]=v_{\mathrm{s}} \mathrm{t}+\left(v_{\mathrm{i}}-\right.$ $\left.v_{\mathrm{S}}\right)\left(1-\exp \left(-k_{\mathrm{obs}} \mathrm{t}\right)\right) / k_{\mathrm{obs}}+\mathrm{d}$, where $[\mathrm{P}]$ is the product concentration, $v_{\mathrm{s}}$ is the steady state rate, $v_{\mathrm{i}}$ is the initial rate, $k_{\mathrm{obs}}$ is the observed first-order rate constant and $\mathrm{d}$ is the offset. Values $v_{\mathrm{s}}$ were plotted versus inhibitor concentrations [I], and $K_{\mathrm{i}}$ values were obtained by non-linear regression according to $v_{\mathrm{s}}=v_{0} /\left(1+[\mathrm{I}] /\left(K_{\mathrm{i}}\left(1+[\mathrm{S}] / K_{\mathrm{m}}\right)\right)\right.$, where $v_{0}$ is the rate in the absence of the inhibitor. The standard errors refer to this non-linear regression. The $k_{\text {on }}$ values were obtained by linear regression according to $k_{\mathrm{obs}}=[\mathrm{I}] k_{\mathrm{on}} /\left(1+[\mathrm{S}] / K_{\mathrm{m}}\right)+k_{\text {off. }}$ The standard errors refer to this linear regression. 

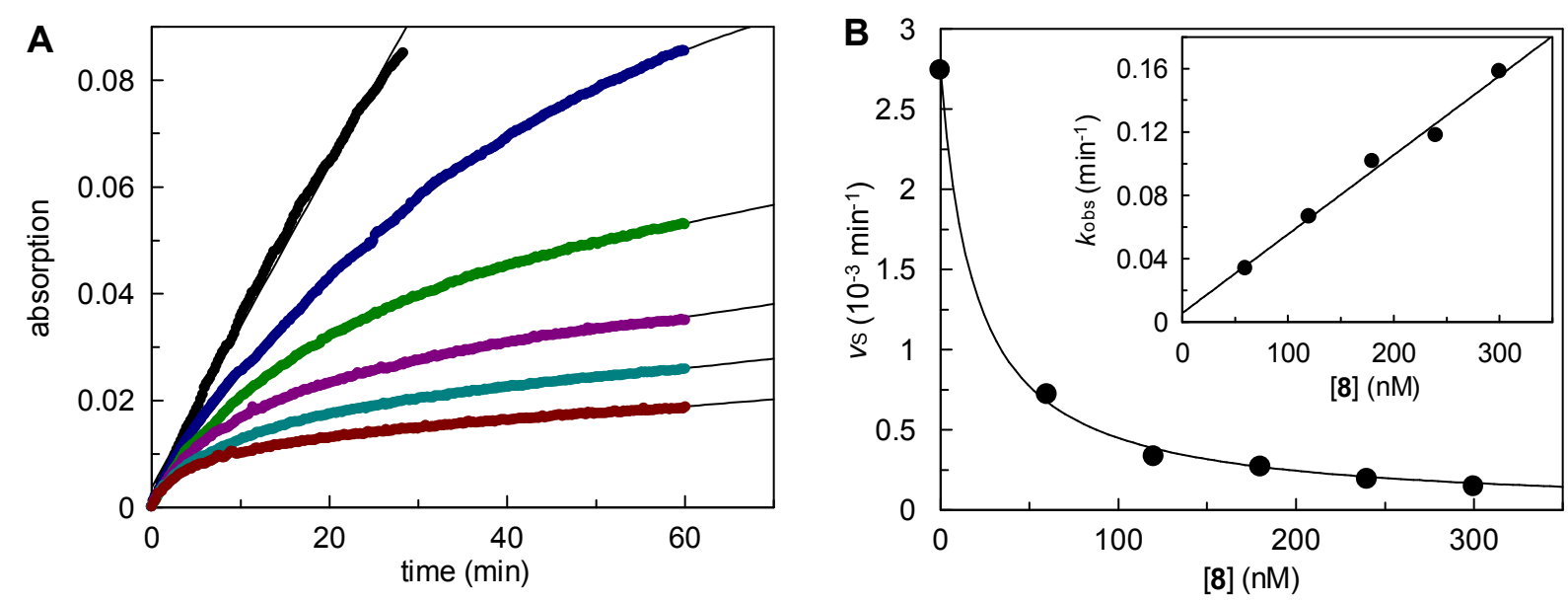

Figure 1. Inhibition of HNE by compound 8. (A) The formation of para-nitroaniline from the chromogenic substrate MeOSuc-Ala-Ala-Pro-Val-pNA was recorded at $405 \mathrm{~nm}$ in the presence of different inhibitor concentrations (from top to bottom: $0 \mathrm{nM}, 60 \mathrm{nM}, 120 \mathrm{nM}, 180 \mathrm{nM}, 240$ nM, $300 \mathrm{nM}$ ). Progress curves were analyzed by non-linear regression using the slow-binding equation $[\mathrm{P}]=v_{\mathrm{s}} \mathrm{t}+\left(v_{\mathrm{i}}-v_{\mathrm{s}}\right)\left(1-\exp \left(-k_{\mathrm{obs}} \mathrm{t}\right)\right) / k_{\mathrm{obs}}+\mathrm{d}$, where $[\mathrm{P}]$ is the product concentration, $v_{\mathrm{s}}$ is the steady-state rate, $v_{\mathrm{i}}$ is the initial rate, $k_{\mathrm{obs}}$ is the observed first-order rate constant, and $\mathrm{d}$ is the offset. (B) Steady-state rates $v_{\mathrm{s}}$ (mean values from duplicate measurements) were plotted versus the inhibitor concentrations. Inset: First-order rate constants $k_{\text {obs }}$ (mean values from duplicate measurements) were plotted versus the inhibitor concentrations. The results are listed in Table 1.

ABP 8 was further evaluated using different serine and cysteine proteases, all of which are characterized by a covalent mode of catalysis. For this purpose, activity assays with chromogenic or fluorogenic peptide substrates were applied (Table 2). Compound 8 caused time-independent inhibition with linear progress curves in case of the human enzymes thrombin, cathepsin B and 
cathepsin $\mathrm{L}$ as well as the bovine enzymes chymotrypsin, factor Xa and trypsin. In contrast, time-dependent inactivation was observed for HNE (see above) and porcine pancreatic elastase (PPE). In order to quote comparable values, half maximal inhibitory concentrations, corrected by the substrate concentration, are given in Table 2. These data indicate the strong preference of ABP 8 to inhibit the target enzyme HNE.

Table 2. Inhibition of Proteases by Probe $\mathbf{8}^{\mathrm{a}}$

\begin{tabular}{cc}
\hline Protease & $\mathrm{IC}_{50}\left(1+[\mathrm{S}] / K_{\mathrm{m}}\right)^{-1}(\mu \mathrm{M})$ \\
\hline HNE & $0.0189 \pm 0.0019$ \\
PPE & $2.27 \pm 0.30$ \\
chymotrypsin & $6.48 \pm 0.85$ \\
thrombin & $5.87 \pm 0.64$ \\
factor Xa & $18.9 \pm 1.0$ \\
trypsin & $>30$ \\
cathepsin B & $9.49 \pm 0.71$ \\
cathepsin L & $0.353 \pm 0.116$ \\
\hline
\end{tabular}

${ }^{a}$ Enzymatic activity was determined with five different inhibitor concentrations, [I], in duplicate measurements. The product formation within 60 min was used to determine $v$ values, as rates of the reaction. $\mathrm{IC}_{50}$ values were obtained by non-linear regression using the equation $v=v_{0} /(1+$ $\left.[\mathrm{I}] / \mathrm{IC}_{50}\right)$, where $v_{0}$ is the rate in the absence and $v$ the rate in the presence of the inhibitor. Values, corrected by the factor $\left(1+[\mathrm{S}] / K_{\mathrm{m}}\right)$ are given. The standard errors refer to the non-linear regression. 
The photophysical properties of ABP 8 were analyzed in three solvents, i.e. $\mathrm{CH}_{2} \mathrm{Cl}_{2}, \mathrm{CH}_{3} \mathrm{OH}$ and $\mathrm{H}_{2} \mathrm{O}$ (Fig. 2). The spectra of $\mathbf{8}$ exhibited slight bathochromic shifts for both absorption maxima and emission maxima with increasing polarity of the solvent and Stokes shifts between 34-44 nm. Thus, due to the properties of the coumarin 343 moiety, probe 8 appears to be qualified to act as the final fluorescence acceptor in FRET systems.

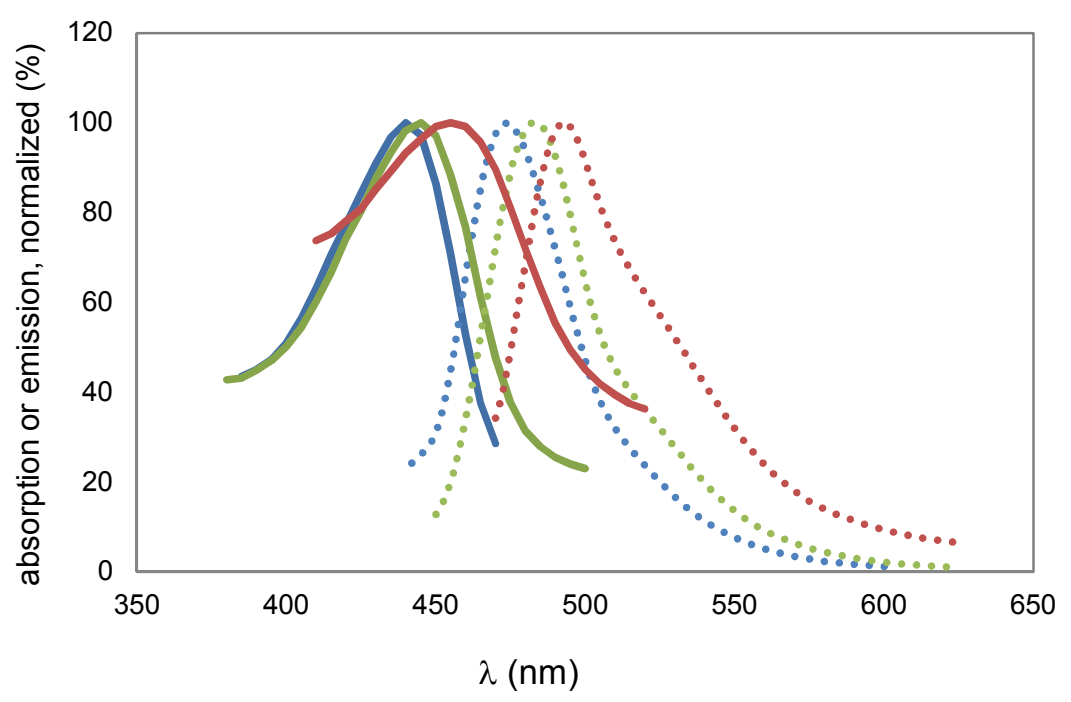

Figure 2. Absorption (5 $\mu \mathrm{M}, 1 \%$ DMSO, solid lines) and emission ( $1 \mu \mathrm{M}, 1 \% \mathrm{DMSO}, \mathrm{PMT}$ value of $400 \mathrm{~V}$, dotted lines) spectra of compound 8 recorded in $\mathrm{H}_{2} \mathrm{O}$ (red lines), $\mathrm{CH}_{3} \mathrm{OH}$ (green lines) and $\mathrm{CH}_{2} \mathrm{Cl}_{2}$ (blue lines), respectively. Absorption and emission maxima were as follows, $\lambda_{\mathrm{ex}}=450 \mathrm{~nm}, \lambda_{\mathrm{em}}=492 \mathrm{~nm}\left(\mathrm{H}_{2} \mathrm{O}\right), \lambda_{\mathrm{ex}}=440 \mathrm{~nm}, \lambda_{\mathrm{em}}=484 \mathrm{~nm}\left(\mathrm{CH}_{3} \mathrm{OH}\right), \lambda_{\mathrm{ex}}=440 \mathrm{~nm}$, $\lambda_{\mathrm{em}}=474 \mathrm{~nm}\left(\mathrm{CH}_{2} \mathrm{Cl}_{2}\right)$. 
To exploit a first FRET system, excessive PPE was incubated with ABP 8 at different concentrations and the reaction was followed over $60 \mathrm{~min}$. Data of the first $33 \mathrm{~min}$ are shown in Figure 3. A wavelength of $320 \mathrm{~nm}$ was used for the excitation of anthranilic acid moieties which can function as the donor in an energy transfer process. The fluorescence kinetics was monitored with the emission wavelength of the coumarin 343 acceptor at $490 \mathrm{~nm}$. The progress curves were analyzed by non-linear regression. In the absence of PPE, a gain in fluorescence was not observed for each ABP concentration (solid lines at the bottom of Fig. 3A). These findings clearly reflect the enzyme-catalyzed transformation of the probe. The formation of anthranilic acid derivative(s) was governed solely by the initial concentration of the probe $\mathbf{8}$ and the reactions obeyed a pseudo-first order kinetics. Accordingly, the initial rates linearly correlated with the concentration of the substrate, i.e. probe $\mathbf{8}$ (Fig. 3B). The product concentration at infinite time also depended on the initial concentration of 8 . In the course of the reaction, the fluorescence intensity approached constant values, which, however, might result from enzymebound and released anthranilic acid derivatives, both being capable to transfer energy to the coumarin acceptor. Although the surrounding environment of the anthranilic acid fluorophore changes upon hydrolysis, the constant fluorescence intensity indicate a similar behavior in the $\lambda_{\text {ex }} 320 \mathrm{~nm}$ FRET system . As depicted in Scheme 3 and supported by the $\lambda_{\text {ex }} 320 \mathrm{~nm}$ FRET experiment, ABP 8 interacts with PPE under ring opening and formation of the anthranoyl enzyme (9) which represents the covalently inhibited enzyme species. The consumption of $\mathbf{8}$ in this Lossen-type conversion is irreversible, but a fraction of the protease can recover its activity when 9 undergoes hydrolysis and the product of the enzyme-catalyzed conversion (10) is released. 

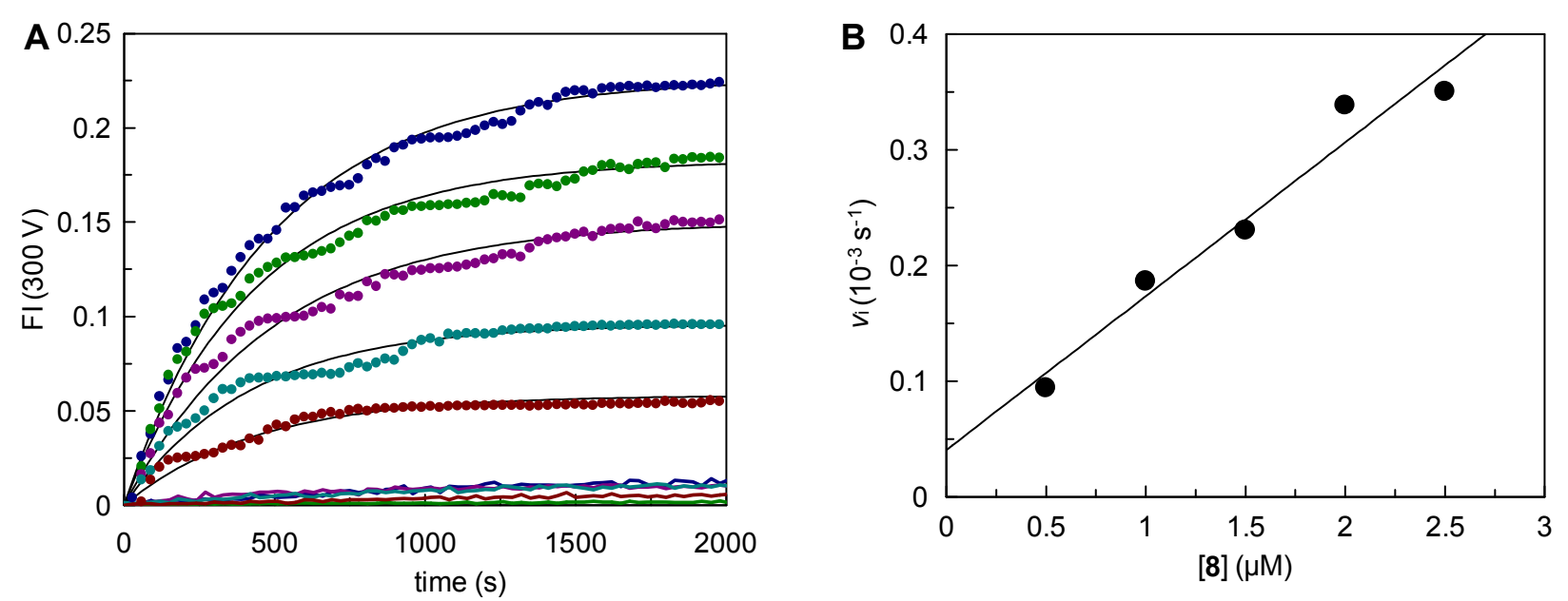

Figure 3. Fluorescence kinetics of the interaction of probe 8 with PPE. A $\lambda_{\text {ex }} 320 \mathrm{~nm}$ FRET between two fluorophores was employed. The excitation of the anthranilic acid fluorophore at $320 \mathrm{~nm}$ led to an energy transfer to the coumarin fluorophore, whose emission was detected at $490 \mathrm{~nm}$. (A) The progress curves over 33 min are shown. They were recorded in the presence of PPE (3.1 U/mL) and five different concentrations of 8, from top to bottom: $2.5 \mu \mathrm{M}, 2.0 \mu \mathrm{M}, 1.5$ $\mu \mathrm{M}, 1.0 \mu \mathrm{M}, 0.5 \mu \mathrm{M}$. Reactions in the absence of PPE are shown as solid lines. Progress curves over 60 min were analyzed using the exponential equation $\mathrm{FI}=v_{\mathrm{i}}\left(1-\exp \left(-k_{\mathrm{obs}} \mathrm{t}\right)\right) / k_{\mathrm{obs}}+\mathrm{d}$, where FI is the fluorescence intensity as generated by the $\lambda_{\text {ex }} 320 \mathrm{~nm} \mathrm{FRET}$, $v_{\mathrm{i}}$ is the initial rate, $k_{\mathrm{obs}}$ is the observed first-order rate constant and $\mathrm{d}$ is the offset. (B) The values $v_{\mathrm{i}}$ (means of two independent experiments) were plotted versus concentrations of probe $\mathbf{8}$. 

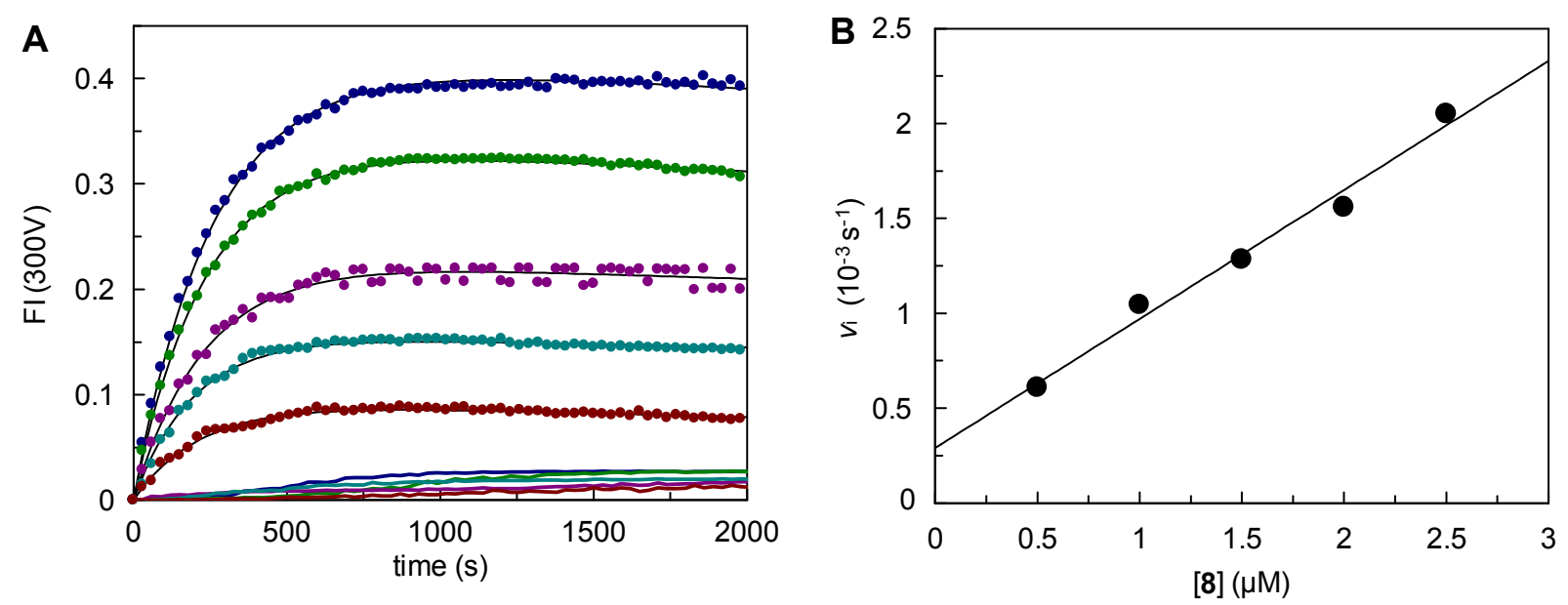

Figure 4. Fluorescence kinetics of the interaction of probe 8 with PPE. A $\lambda_{\text {ex }} 285 \mathrm{~nm}$ FRET between three fluorophores was assumed. An excitation of the tryptophan fluorophore of PPE at $285 \mathrm{~nm}$ would lead to the first, hypothesized energy transfer from tryptophan to the second, anthranilic acid fluorophore. Its excitation produced the second energy transfer to the coumarin fluorophore, whose emission was detected at $490 \mathrm{~nm}$. (A) The progress curves over 33 min are shown. They were recorded in the presence of PPE $(3.1 \mathrm{U} / \mathrm{mL})$ and five different concentrations of 8, from top to bottom: $2.5 \mu \mathrm{M}, 2.0 \mu \mathrm{M}, 1.5 \mu \mathrm{M}, 1.0 \mu \mathrm{M}, 0.5 \mu \mathrm{M}$. Reactions in the absence of PPE are shown as solid lines. Progress curves over 60 min were analyzed using the slow-binding equation $\mathrm{FI}=v_{\mathrm{s}} \mathrm{t}+\left(v_{\mathrm{i}}-v_{\mathrm{s}}\right)\left(1-\exp \left(-k_{\mathrm{obs}} \mathrm{t}\right)\right) / k_{\mathrm{obs}}+\mathrm{d}$, where FI is the fluorescence intensity as generated by the $\lambda_{\mathrm{ex}} 285 \mathrm{~nm}$ FRET, $v_{\mathrm{s}}$ is the steady state rate, $v_{\mathrm{i}}$ is the initial rate, $k_{\mathrm{obs}}$ is the observed first-order rate constant and $\mathrm{d}$ is the offset. (B) The values $v_{\mathrm{i}}$ (means of two independent experiments) were plotted versus concentrations of probe $\mathbf{8}$. 
Scheme 3. Assumed FRET Systems to Study the Interaction of Probe $\mathbf{8}$ with Elastase ${ }^{\mathrm{a}}$<smiles>CON1C(=O)c2ccc(C(=O)c3cc4cc5c6c(c4oc3=O)CCCN6CCC5)cc2C1=O</smiles>

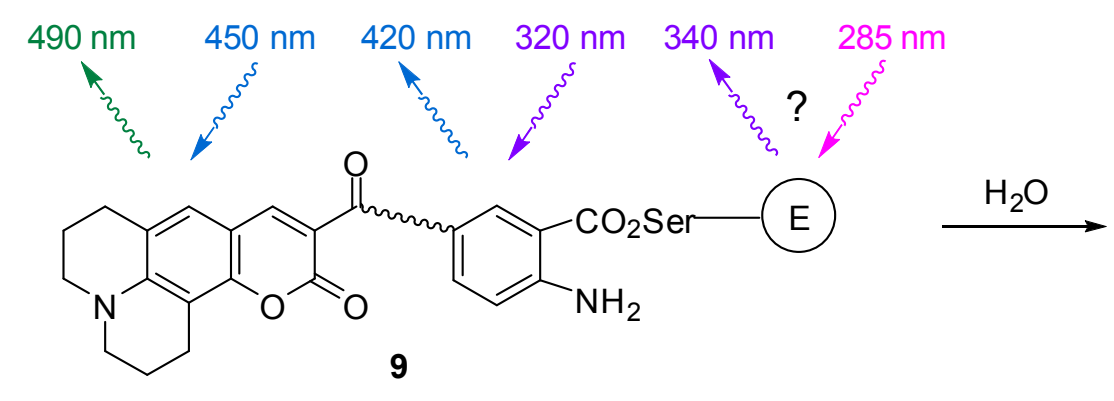<smiles>Nc1ccc(C(=O)c2cc3cc4c5c(c3oc2=O)CCCN5CCC4)cc1C(=O)OCCCCCCOC(=O)O</smiles>

${ }^{a}$ A supposed $\lambda_{\text {ex }} 285 \mathrm{~nm}$ FRET between the enzyme's tryptophan (excitation $285 \mathrm{~nm}$ ) and coumarin 343 (emission $490 \mathrm{~nm}$ ). A $\lambda_{\mathrm{ex}} 320 \mathrm{~nm}$ FRET between the anthranilic acid moiety (excitation $320 \mathrm{~nm}$ ) and coumarin 343 (emission $490 \mathrm{~nm}$ ).

Next, it was intended to comprise the tryptophan fluorescence of PPE. For the generation of a FRET signal, there are two tryptophan residues in a sufficient distance to the active site. ${ }^{36}$ These distances of about 11-12 $\AA$ were estimated by building a model of a covalent complex, see Supporting Information (SI, Fig. S1). For this purpose, we have modeled the active site of PPE 
with the catalytic serine residue bound to an unsubstituted anthranoyl residue, representing a simplified model of complex 9 (Scheme 3). The phenyl ring of the resulting Ser195-anthranilic acid ester complex acts as a fluorophore that can be excited by the nearby tryptophan moieties.

The following FRET kinetic experiments have been designed to include the excitation of tryptophan at $285 \mathrm{~nm}$, which, in turn, might excite the anthranilic acid fluorophore, leading to the excitation of the coumarin moiety and the emission at $490 \mathrm{~nm}$ (Scheme 3). Except of the excitation wavelength, the $\lambda_{\mathrm{ex}} 285 \mathrm{~nm}$ FRET experiment was performed under the same conditions as described above. We monitored a strong increase in fluorescence intensity within the first $15 \mathrm{~min}$, which expectedly depended on the initial concentration of the probe 8 (Fig. 4A). A slow decrease in fluorescence intensity at the later stage of the reaction was observed. Accordingly, an equation for the non-linear regression of the progress curves was used which includes final slopes different from zero. The pseudo-first order kinetics was confirmed also for this process by demonstrating the linear correlation between the initial rates and the concentrations of probe $\mathbf{8}$ as shown in the corresponding secondary plot (Fig. 4B).

The $\lambda_{\text {ex }} 285 \mathrm{~nm}$ FRET setup provided experimental support for the formation of an enzymeprobe complex which contains the anthranilic acid fluorophore (i.e. complex 9, Scheme 3). The modified probe $\mathbf{1 0}$ was probably not recorded due to the interruption of the FRET system when complex 9 dissociated. Thus, the slow hydrolytic cleavage of 9 was supposed to account for the late decrease of the fluorescence signal. In a separate experiment, fluorescence kinetics was followed over 8 hours by applying the same $\lambda_{\text {ex }} 285 \mathrm{~nm}$ FRET setup. After reaching maximal fluorescence intensity, an exponential decrease was observed. The progress curves of this later stage were monitored and analyzed with the equation of the exponential decay, see Supporting Information (SI, Fig. S2). The half-live of the anthranoyl enzyme 9 which is capable of 
producing the $\lambda_{\text {ex }} 285 \mathrm{~nm}$ FRET was estimated to be 3.3 hours. This value, obtained by fluorescence kinetics with PPE, is in the same range as the half-live of $71 \mathrm{~min}$ as obtained from inhibition kinetics with HNE. The difference is assumed to be mainly due to the origin of the enzyme in both experiments. The decay of this complex 9 indicates the involvement of tryptophan residue(s) in the first energy transfer step. These assumption is furthermore supported by afore-described inhibition kinetics with mesyloxyphthalimides which showed steady-state rates different from zero, again reflecting a slow release of the ring-opened probe and the simultaneous recovery of the protease. However, further experimental evidence is needed to clarify the involvement of tryptophan(s) in the $\lambda_{\mathrm{ex}} 285 \mathrm{~nm}$ FRET system. For example, in future studies, the FRET efficiency might be examined with the enzyme mutated on the two tryptophan residues in proximity to the active site.

The suitability of compound $\mathbf{8}$ as an activity-based probe was proved by in-gel fluorescence analysis of HNE (Fig. 5). HNE at different concentrations was treated with $2.5 \mu \mathrm{M}$ of $\mathbf{8}$ for 20 min. Following SDS-PAGE, fluorescent bands at approximately $29 \mathrm{kDa}$ could be detected and amounts as low as $160 \mathrm{ng}$ of HNE successfully visualized (lanes 1-5 in Fig. 5A). Three bands were observed for HNE (e.g. lane 2 in Fig. 5B, lane 2-3 in Fig. 5C). It is known that several HNE isoforms can be resolved by SDS-PAGE and that these catalytically active forms only differ in their carbohydrate content. Moreover, the self-cleavage of elastase from murine and human neutrophils was shown to generate variants of different catalytic activity. ${ }^{37}$ Since elastase used in our study was prepared from human neutrophils, we assume that the three bands correspond to HNE isoforms with different glycosylation patterns or are caused by autocatalytic cleavage.

The binding mode of probe $\mathbf{8}$ in the active site of HNE was verified by a competition experiment (Fig. 5B). HNE was incubated for 5 min with $5 \mu \mathrm{M}$ of the active-site directed, 
covalent inhibitor sivelestat, ${ }^{4}$ followed by $2.5 \mu \mathrm{M}$ of ABP 8 (lane 1 in Fig. 5B). In the control experiment, HNE was incubated with DMSO prior to the addition of the probe (lane 2 in Fig. 5B). Sivelestat was able to protect HNE from a reaction with the probe as the detectable fluorescence at $\sim 29 \mathrm{kDa}$ was strongly reduced. These findings confirmed the active-site directed interaction of $\mathbf{8}$ with HNE and indicated that surface nucleophiles of the enzyme were obviously not affected by probe $\mathbf{8}$.

Furthermore, the selectivity of HNE labeling by $\mathbf{8}$ was studied as illustrated in Figures $5 \mathrm{C}$ and 5D. HEK293 cell lysate was spiked with HNE, incubated with the probe, subjected to SDSPAGE and analyzed by fluorescence imaging. In contrast to the imaging of $600 \mathrm{ng}$ of HNE (lane 2 in Fig. 5C), amounts of $9 \mu \mathrm{g}$ HEK cell lysate protein did not produce fluorescent bands (lane 1 in Fig. 5C), indicating that $\mathbf{8}$ did not react with non-target proteins. As a control, the gel was subsequently stained with Coomassie blue (lanes 1 and 2 in Fig. 5D). We performed two spiking experiments (lanes 3 and 4 in Figures 5C and 5D). HEK lysate was added either after the incubation to the mixture of HNE and $\mathbf{8}$, or prior to the incubation. When HNE was incubated with $\mathbf{8}$ only, the protease has been inactivated due to reaction with $\mathbf{8}$ and, thus, became unable to degrade the lysate's proteins. Therefore, the Coomassie staining of the protein mixtures in lanes 1 and 3 (Fig. 5D) was similar. However, when HNE was simultaneously incubated with the lysate and $\mathbf{8}$, protein degradation occurred and the enzyme was partly protected from being inactivated by 8 due to the consumption of protein substrates. This led to a different protein pattern (lane 4 versus lane 3 in Fig. 5D) and to a slightly reduced intensity of the fluorescent signal of HNE (lane 4 versus lane 3 in Fig. 5C). Importantly, this analysis revealed selective labeling of the target HNE within a mixture of excess proteins without detectable nonspecific interactions of 8 (lanes 3 and 4 in Fig. 5C). 
Therefore, in the course of this study, we thought to assess the suitability of ABP $\mathbf{8}$ for detecting endogenous elastase. For this purpose, neutrophil granulocytes from human donors were purified by density gradient centrifugation and lysates were prepared by detergent (Triton X-100) treatment. The following analysis by gel electrophoresis of the lysate proteome revealed a fluorescent band at $29 \mathrm{kDa}$ which could clearly be assigned to HNE (lane 3 in Fig. 6A). In the competition experiment, it was shown, that the addition of sivelestat prior to the probe $\mathbf{8}$ was able to abolish HNE labeling (lane 2 in Fig. 6A), again indicating that both, probe 8 and sivelestat, target the active site of HNE. The Coomassie blue staining (lanes 1-3 in Fig. 6B) indicated that the endogenous amount of HNE was not particularly prominent in the lysate. Thus, this in-lysate experiment even more accentuated the strong labeling capability of our activity-based probe. 


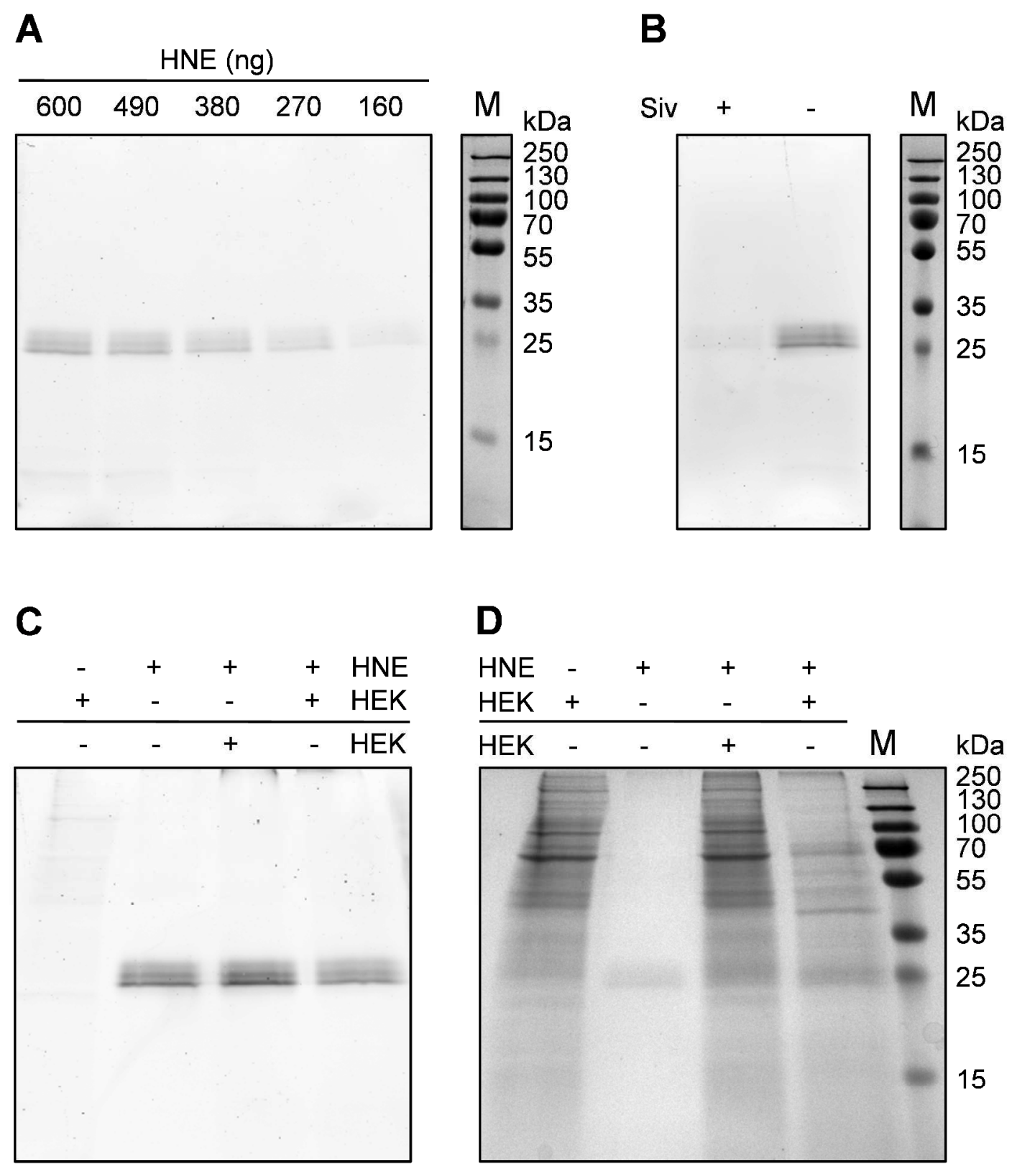

Figure 5. Imaging of HNE with the fluorescent probe 8. (A) HNE in different concentrations (11 $-40 \mathrm{ng} / \mu \mathrm{L}$ ) was incubated with $2.5 \mu \mathrm{M}$ of 8 for $20 \mathrm{~min}$ at $25^{\circ} \mathrm{C}$. The mixtures were subjected to reducing SDS-PAGE. The amounts of HNE applied to individual lanes are indicated. (B) HNE (40 ng/ $\mu \mathrm{L})$ was preincubated in the presence or absence of $5 \mu \mathrm{M}$ of sivelestat (Siv) for $5 \mathrm{~min}$ at $25^{\circ} \mathrm{C}$. Probe $8(2.5 \mu \mathrm{M})$ was added, the mixtures were incubated for further $20 \mathrm{~min}$ at $25^{\circ} \mathrm{C}$ and 
subjected to reducing SDS-PAGE. (C) Lanes 1 and 2: HEK cell lysate $(0.60 \mu \mathrm{g} / \mu \mathrm{L})$ or HNE $(40 \mathrm{ng} / \mu \mathrm{L})$ were incubated for $20 \mathrm{~min}$ at $25^{\circ} \mathrm{C}$ in the presence of $2.5 \mu \mathrm{M}$ of 8 and subjected to reducing SDS-PAGE. Lanes 3 and 4: $\mathrm{HNE}(40 \mathrm{ng} / \mu \mathrm{L})$ was incubated for $20 \mathrm{~min}$ at $25^{\circ} \mathrm{C}$ in the presence of $2.5 \mu \mathrm{M}$ of 8 and HEK lysate $(0.60 \mu \mathrm{g} / \mu \mathrm{L})$ was added after the incubation. A mixture HNE $(40 \mathrm{ng} / \mu \mathrm{L})$ and HEK lysate $(0.60 \mu \mathrm{g} / \mu \mathrm{L})$ were incubated in the presence of $2.5 \mu \mathrm{M}$ of $\mathbf{8}$. Both mixtures were subjected to reducing SDS-PAGE. (D) After SDS-PAGE described in (C), the proteins in were visualized by Coomassie staining. (A-D) M, molecular mass marker.

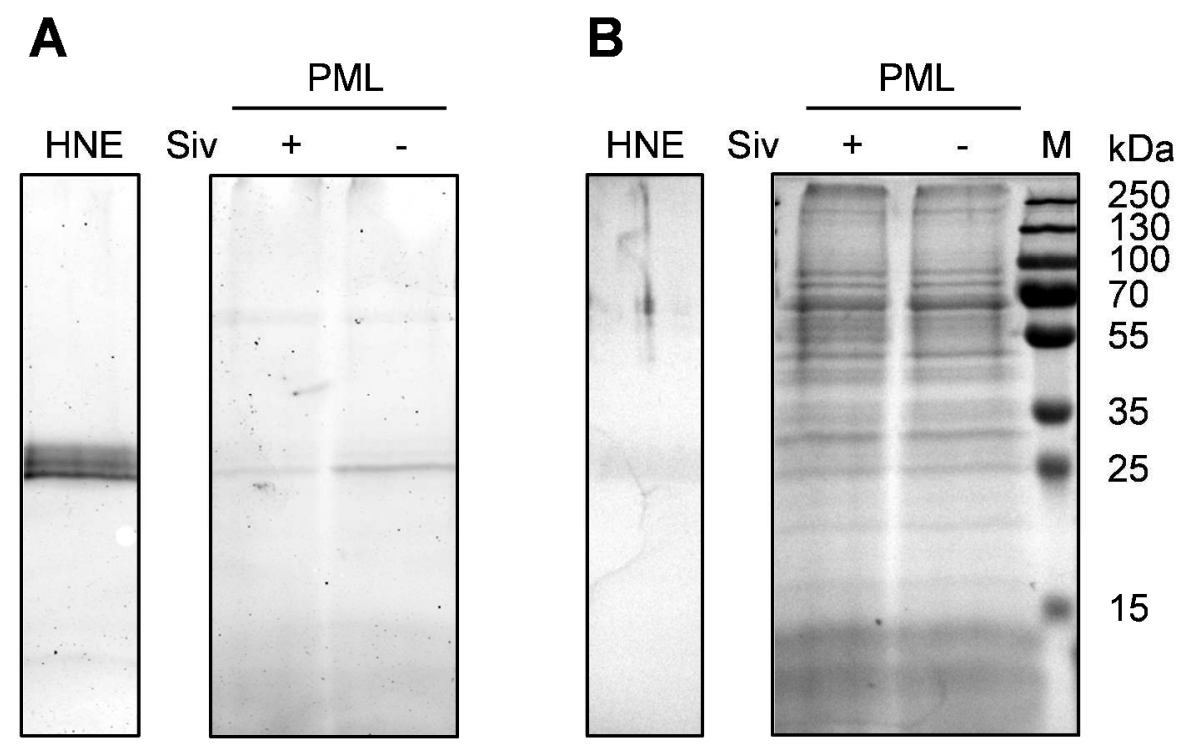

Figure 6. Imaging of endogenous HNE with probe 8. (A) HNE (40 $\mathrm{ng} / \mu \mathrm{L})$ and lysate of human polymorphonuclear leukocytes (PML), in the presence or absence of $5 \mu \mathrm{M}$ of sivelestat (Siv), were incubated with $2.5 \mu \mathrm{M}$ of 8 for 20 min at $25{ }^{\circ} \mathrm{C}$. The mixtures were subjected to reducing SDS-PAGE. (B) After SDS-PAGE, the proteins in were visualized by Coomassie staining. M, molecular mass marker. 


\section{CONCLUSIONS}

In conclusion, we have developed a novel fluorescent probe for human neutrophil elastase. For the chemical design, a phthalimide precursor for a Lossen rearrangement was chosen. The Lossen rearrangement to functionalized isocyanates gives rise to a variety of inter- and intramolecular transformations. While it has accordingly been applied to manifold preparative purposes, its application for activity-based probing has been reported herein for the first time. In the fluorescence kinetic experiments, two FRET systems $\left(\lambda_{\text {ex }} 320 \mathrm{~nm}\right.$ FRET and $\lambda_{\text {ex }} 285 \mathrm{~nm}$ FRET) were employed and it was shown that the observed fluorescence transfers exclusively arose from the interaction of the ABP with the target protease. The applicability of the probe was demonstrated by in-gel fluorescent detection analyses. Our probe was capable to visualize endogenous elastase from human neutrophils. The activity-based probe is expected to serve as a valuable tool compound for future investigations of elastase, a therapeutically relevant protease, and neutrophil-mediated proteolytic events. 
ASSOCIATED CONTENT

Supporting Information. Covalent docking experiments, a $\lambda_{\text {ex }} 285 \mathrm{~nm}$ FRET experiment, all synthetic procedures, ${ }^{1} \mathrm{H}$ and ${ }^{13} \mathrm{C}$ NMR spectra of newly synthesized compounds.

\section{AUTHOR INFORMATION}

\section{Corresponding Author}

Pharmaceutical Institute, Pharmaceutical Chemistry I, An der Immenburg 4, D-53121 Bonn, Germany. Phone: +49-228-732317. Fax:+49-228-732567. E-mail: guetschow@uni-bonn.de

\section{Author Contributions}

M.G. conceived the study. A.C.S.F., A.S.T., A.B., T.G. and E.G. performed experiments. All authors analyzed data. A.C.S.F., A.B., J.B., S.N. and M.G. wrote the manuscript.

\section{ACKNOWLEDGMENT}

A.S.F. was supported by a fellowship from the DAAD (IPID4all program). The authors thank Marit Stirnberg, Anna-Madeleine Beckmann and Martin Mangold for providing cell lysates, Oscar M. Bautista-Aguilera for synthetic support and Anke Gühler for technical assistance. 


\begin{abstract}
ABBREVIATIONS
ABP, activity-based probe; ALI, acute lung injury; ARDS, acute respiratory distress syndrome; DAD, diode array detection; DIPEA, diisopropylethylamine; FRET, Förster resonance energy transfer; HATU, $O$-(7-azabenzotriazol-1-yl)- $N, N, N^{\prime}, N^{\prime}$-tetramethyluronium-hexafluorphosphat; HEK, human embryonic kidney; HNE, human neutrophil elastase; $\mathrm{LTB}_{4}$, leukotriene $\mathrm{B}_{4}$; PEG, polyethylene glycol; PMT, photomultiplier tube; pNA, para-nitroanilide; PPE, porcine pancreatic elastase; siv, sivelestat.
\end{abstract}

\title{
REFERENCES
}

(1a) Korkmaz, B., Moreau, T., and Gauthier, F. (2008) Neutrophil elastase, proteinase 3 and cathepsin G: physicochemical properties, activity and physiopathological functions. Biochimie 90, 227-242. (b) Korkmaz, B., Horwitz, M. S., Jenne, D. E., and Gauthier, F. (2010) Neutrophil elastase, proteinase 3, and cathepsin G as therapeutic targets in human diseases. Pharmacol. Rev. 62, 726-759. (c) Lucas, S. D., Costa, E., Guedes, R. C., and Moreira, R. (2013) Targeting COPD: advances on low-molecular-weight inhibitors of human neutrophil elastase. Med. Res. Rev. E73-101. (d) von Nussbaum, F., and Li, V. M. (2015) Neutrophil elastase inhibitors for the treatment of (cardio)pulmonary diseases: Into clinical testing with pre-adaptive pharmacophores. Bioorg. Med. Chem. Lett. 25, 4370-4381.

(2) Brinkmann, V., Reichard, U., Goosmann, C., Fauler, B., Uhlemann, Y., Weiss, D. S., Weinrauch, Y., and Zychlinsky, A. (2004) Neutrophil extracellular traps kill bacteria. Science $303,1532-1535$. 
(3a) Young, R. E.; Voisin, M. B.; Wang, S., Dangerfield, J., and Nourhsargh, S. (2007) Role of neutrophil elastase in LTB4-induced neutrophil transmigration in vivo assessed with a specific inhibitor and neutrophil elastase deficient mice. Br. J. Pharmacology 151, 628-637. (b) Colom, B., Bodkin, J. V., Beyrau, M., Woodfin, A., Ody, C., Rourke, C., Chavakis, T., Brohi, K., Imhof, B. A., and Nourshargh, S. (2015) Leukotriene $\mathrm{B}_{4}$-neutrophil elastase axis drives neutrophil reverse transendothelial cell migration in vivo. Immunity 42, 1075-1086. (c) Reglero-Real, N., Colom, B., Bodkin, J. V., and Nourshargh, S. (2016) Endothelial cell junctional adhesion molecules: role and regulation of expression in inflammation. Arterioscler. Thromb. Vasc. Biol. $36,2048-2057$.

(4a) Kawabata, K., Suzuki, M., Sugitani, M., Imaki, K., Toda, M., and Miyamoto, T. (1991) ONO-5046, a novel inhibitor of human neutrophil elastase. Biochem. Biophys. Res. Commun. 177, 814-820. (b) Nakayama, Y., Odagaki, Y., Fujita, S., Matsuoka, S., Hamanaka, N., Nakai, H., and Toda, M. (2002) Clarification of mechanism of human sputum elastase inhibition by a new inhibitor, ONO-5046, using electrospray ionization mass spectrometry. Bioorg. Med. Chem. Lett. 12, 2349-2353.

(5) Winiarski, Ł., Oleksyszyn, J., and Sieńczyk, M. (2012) Human neutrophil elastase phosphonic inhibitors with improved potency of action. J. Med. Chem. 55, 6541-6553.

(6) Krantz, A., Spencer, R. W., Tam, T. F., Thomas, E., and Copp, L. J. (1987) Design of alternate substrate inhibitors of serine proteases. Synergistic use of alkyl substitution to impede enzyme-catalyzed deacylation. J. Med. Chem. 30, 489-491.

(7a) Mulchande, J.; Guedes, R. C.; Tsang, W. Y.; Page, M. I.; Moreira, R.; and Iley, J. (2008) Azetidine-2,4-diones (4-oxo-beta-lactams) as scaffolds for designing elastase inhibitors. J. Med. Chem. 51, 1783-1790. (b) Mulchande, J.; Oliveira, R., Carrasco, M., Gouveia, L., Guedes, R. C., 
Iley, J., and Moreira, R. (2010) 4-Oxo-beta-lactams (azetidine-2,4-diones) are potent and selective inhibitors of human leukocyte elastase. J. Med. Chem. 53, 241-253. (c) Groutas, W. C., Houser-Archield, N., Chong, L. S., Venkataraman, R., Epp, J. B., Huang, H., and McClenahan, J. J. (1993) Efficient inhibition of human leukocyte elastase and cathepsin G by saccharin derivatives. J. Med. Chem. 36, 3178-3181.

(8) Lucas, S. D., Gonçalves, L. M., Carvalho, L. A., Correia, H. F., Da Costa, E. M., Guedes, R. A., Moreira, R., and Guedes, R. C. (2013) Optimization of O3-acyl kojic acid derivatives as potent and selective human neutrophil elastase inhibitors. J. Med. Chem. 56, 9802-9806.

(9) Köcher, S., Rey, J., Bongard, J., Tiaden, A. N., Meltzer, M., Richards, P. J., Ehrmann, M., and Kaiser, M. (2017) Tailored Ahp-cyclodepsipeptides as potent non-covalent serine protease inhibitors. Angew. Chem. Int. Ed. 56, 8555-8558.

(10a) Patel, N., Belcher, J., Thorpe, G., Forsyth, N. R., and Spiteri, M. A. (2015) Measurement of C-reactive protein, procalcitonin and neutrophil elastase in saliva of COPD patients and healthy controls: Correlation to self-reported wellbeing parameters. Respir. Res. 16:62. (b) Chalmers, J. D., Moffitt, K. L., Suarez-Cuartin, G., Sibila, O., Finch, S., Furrie, E., Dicker, A., Wrobel, K., Elborn, J. S., Walker, B., Martin, S. L., Marshall, S. E., Huang, J. T., and Fardon, T. C. (2017) Neutrophil elastase activity is associated with exacerbations and lung function decline in bronchiectasis. Am. J. Respir. Crit. Care Med. 195, 1384-1393. (c) Bihlet, A. R., Karsdal, M. A., Sand, J. M., Leeming, D. J., Roberts, M., White, W., and Bowler, R. (2017) Biomarkers of extracellular matrix turnover are associated with emphysema and eosinophilic-bronchitis in COPD. Respir. Res. 18:22.

(11a) Sabidó, E., Tarragó, T., Niessen, S., Cravatt, B. F., and Giralt, E. (2009) Activity-based probes for monitoring postproline protease activity. ChemBioChem 10, 2361-2366. (b) Sabidó, 
E., Tarragó, T., and Giralt, E. (2010) Towards the identification of unknown neuropeptide precursor-processing enzymes: Design and synthesis of a new family of dipeptidyl phosphonate activity probes for substrate-based protease identification. Bioorg. Med. Chem. 18, 8350-8355. (c) Sanman, L. E., and Bogyo, M. (2014) Activity-Based Profiling of Proteases. Annu. Rev. Biochem. 83, 249-273. (d) Willems, L. I., Overkleeft, H. S., and van Kasteren, S. I. (2014) Current developments in Activity-Based Protein Profiling. Bioconjugate Chem. 25, 1181-1191. (e) de Bruin, G., Xin, B. T., Kraus, M., van der Stelt, M., van der Marel, G. A., Kisselev, A. F., Driessen, C., Florea, B. I., and Overkleeft, H. S.(2016) A set of activity-based probes to visualize human (immuno)proteasome activities. Angew. Chem. Int. Ed. Engl. 55, 4199-4203. (f) van Kasteren, S. I., Florea, B. I., and Overkleeft, H. S. (2017) Activity-based protein profiling: From chemical novelty to biomedical stalwart. Methods Mol. Biol. 1491:1-8. (g) Zweerink, S., Kallnik, V., Ninck, S., Nickel, S., Verheyen, J., Blum, M., Wagner, A., Feldmann, I., Sickmann, A., Albers, S. V., Bräsen, C., Kaschani, F., Siebers, B., and Kaiser, M. (2017) Activity-based protein profiling as a robust method for enzyme identification and screening in extremophilic Archaea. Nat. Commun. 8:15352.

(12) Haedke, U., Götz, M., Baer, P., and Verhelst, S. H. (2012) Alkyne derivatives of isocoumarins as clickable activity-based probes for serine proteases. Bioorg. Med. Chem. 20, $633-640$.

(13) Shannon, D. A., Gu, C., McLaughlin, C. J., Kaiser, M., van der Hoorn, R. A., and Weerapana, E. (2012) Sulfonyl fluoride analogues as activity-based probes for serine proteases. ChemBioChem 13, 2327-2330. 
(14) Ruivo, E. F., Gonçalves, L. M., Carvalho, L. A., Guedes, R. C., Hofbauer, S., Brito, J. A., Archer, M., Moreira, R., and Lucas, S. D. (2016) Clickable 4-oxo- $\beta$-lactam-based selective probing for human neutrophil elastase related proteomes. ChemMedChem 11, 2037-2042.

(15a) Serim, S., Mayer, S. V., and Verhelst, S. H. (2013) Tuning activity-based probe selectivity for serine proteases by on-resin "click" construction of peptide diphenyl phosphonates. Org. Biomol. Chem. 11, 5714-5721. (b) Lechtenberg, B. C., Kasperkiewicz, P., Robinson, H., Drag, M., and Riedl, S. J. (2015) The elastase-PK101 structure: mechanism of an ultrasensitive activity-based probe revealed. ACS Chem. Biol. 10, 945-951.

(16a) Gehrig, S., Mall, M. A., and Schultz, C. (2012) Spatially resolved monitoring of neutrophil elastase activity with ratiometric fluorescent reporters. Angew. Chem. Int. Ed. 51, 6258-6261. (b) de Bruin, G., Xin, B. T., Florea, B. I., and Overkleeft, H. S. (2016) Proteasome subunit selective activity-based probes report on proteasome core particle composition in a native polyacrylamide gel electrophoresis fluorescence-resonance energy transfer assay. J. Am. Chem. Soc. 138, 9874-9880. (c) Okamoto, K., and Sako, Y. (2017) Recent advances in FRET for the study of protein interactions and dynamics. Curr. Opin. Struct. Biol. 46, 16-23. (d) Bunt, G., and Wouters, F. S. (2017) FRET from single to multiplexed signaling events. Biophys. Rev. 9, $119-129$.

(17) Gütschow, M., Pietsch, M., Themann, A., Fahrig, J., and Schulze, B. (2005) 2,4,5Triphenylisothiazol-3(2H)-one 1,1-dioxides as inhibitors of human leukocyte elastase. J. Enzyme Inhib. Med. Chem. 20, 341-347.

(18) Castillo, M. J., Nakajima, K., Zimmerman, M., and Powers, J. C. (1979) Sensitive substrates for human leukocyte and porcine pancreatic elastase: a study of the merits of various 
chromophoric and fluorogenic leaving groups in assays for serine proteases. Anal. Biochem. 99, 53-64.

(19) Neumann, U., and Gütschow, M. (1995) 3,1-Benzothiazin-4-ones and 3,1-benzoxazin-4ones: Highly different activities in chymotrypsin inactivation. Bioorg. Chem. 23, 72-88.

(20) Steinebach, C., Schulz-Fincke, A. C., Schnakenburg, G., and Gütschow, M. (2016) In situ generation and trapping of thioimidates: An intermolecular tandem reaction to 4-acylimino-4H3,1-benzothiazines. RSC Advances 6, 15430-15440.

(21) Dosa, S., Stirnberg, M., Lülsdorff, V., Häußler, D., Maurer, E., and Gütschow, M. (2012) Active site mapping of trypsin, thrombin and matriptase-2 by sulfamoyl benzamidines. Bioorg. Med. Chem. 20, 6489-6505.

(22) Häußler, D., Scheidt, T., Stirnberg, M., Steinmetzer, T., and Gütschow, M. (2015) A Bisbenzamidine phosphonate as a Janus-faced inhibitor for trypsin-like serine proteases. ChemMedChem 10, 1641-1646.

(23) Sisay, M. T., Steinmetzer, T., Stirnberg, M., Maurer, E., Hammami, M., Bajorath, J., and Gütschow, M. (2010) Identification of the first low-molecular-weight inhibitors of matriptase-2. J. Med. Chem. 53, 5523-5535.

(24) Frizler, M., Lohr, F., Lülsdorff, M., and Gütschow, M. (2011) Facing the gem-dialkyl effect in enzyme inhibitor design: preparation of homocycloleucine-based azadipeptide nitriles. Chem. Eur. J. 17, 11419-11423.

(25) Häußler, D., Schulz-Fincke, A. C., Beckmann, A. M., Keils, A., Gilberg, E., Mangold, M., Bajorath, J., Stirnberg, M., Steinmetzer, T.; and Gütschow, M. (2017) A fluorescent-labeled phosphono bisbenzguanidine as an activity-based probe for matriptase. Chem. Eur. J. 23, 52055209. 
(26) Neumann, U., and Gütschow, M. (1994) N-(Sulfonyloxy)phthalimides and analogs are potent inactivators of serine proteases. J. Biol. Chem. 269, 21561-21567.

(27) Kerrigan, J. E., Walters, M. C., Forrester, K. J., Crowder, J. B., and Christopher, L. J. (2000) 6-Acylamino-2-[(alkylsulfonyl)oxy]-1H-isoindole-1,3-dione mechanism-based inhibitors of human leukocyte elastase. Bioorg. Med. Chem. Lett. 10, 27-30.

(28) Vagnoni, L. M., Gronostaj, M., and Kerrigan, J. E. (2001) 6-Acylamino-2$1[($ ethylsulfonyl)oxy]-1H-isoindole-1,3-diones mechanism-based inhibitors of human leukocyte elastase and cathepsin G: Effect of chirality in the 6-acylamino substituent on inhibitory potency and selectivity. Bioorg. Med. Chem. 9, 637-645.

(29) Martyn, D. C., Moore, M. J., and Abell, A. D. (1999) Succinimide and saccharin-based enzyme-activated inhibitors of serine proteases. Curr. Pharm. Des. 5, 405-415.

(30) Gütschow, M. (1999) One-pot reactions of $N$-(mesyloxy)phthalimides with secondary amines to 2-ureidobenzamides, 2-ureidobenzoic acids, ethyl 2-ureidobenzoates, or isatoic anhydrides. J. Org. Chem. 64, 5109-5115.

(31) Groutas, W. C., Stanga, M. A., and Brubaker, M. J. (1989) ${ }^{13}$ C NMR evidence for an enzyme-induced Lossen rearrangement in the mechanism-based inactivation of alphachymotrypsin by 3-benzyl-N-((methylsulfonyl)oxy)succinimide. J. Am. Chem. Soc. 111, 19311932.

(32a) Groutas, W. C., Brubaker, M. J., Venkataraman, R., and Stanga, M. A. (1992) Enantioselective inhibition of human leukocyte elastase. Arch. Biochem. Biophys. 297, 144-146. (b) Abell, A. D., Oldham, M. D. (1999) Leucine-phenylalanine dipeptide-based $N$ mesyloxysuccinimides: synthesis of all four stereoisomers and their assay against serine proteases. Bioorg. Med. Chem. Lett. 9, 497-500. 
(33) Groutas, W. C., Huang, H., Epp, J. B., Brubaker, M. J., Keller, C. E., and McClenahan, J. J. (1992) A general approach toward the design of inhibitors of serine proteinases: Inhibition of human leukocyte elastase by substituted dihydrouracils. Bioorg. Med. Chem. Lett. 2, 1565-1570. (34a) Agnes, R. S., Jernigan, F., Shell, J. R., Sharma, V., and Lawrence, D. S. (2010) Suborganelle sensing of mitochondrial cAMP-dependent protein kinase activity. J. Am. Chem. Soc. 132, 6075-6080. (b) Nizamov, S., Willig, K. I., Sednev, M. V., Belov, V. N., and Hell, S. W. (2012) Phosphorylated 3-heteroarylcoumarins and their use in fluorescence microscopy and nanoscopy. Chem. Eur. J. 18, 16339-16348. (c) Mertens, M. D., Schmitz, J., Horn, M., Furtmann, N., Bajorath, J., Mareš, M., and Gütschow, M. (2014) A coumarin-labeled vinyl sulfone as tripeptidomimetic activity-based probe for cysteine cathepsins. ChemBioChem 15, 955-959. (d) Häußler, D., Mangold, M., Furtmann, N., Braune, A., Blaut, M., Bajorath, J., Stirnberg, M., and Gütschow, M. (2016) Phosphono bisbenzguanidines as irreversible dipeptidomimetic inhibitors and activity-based probes of matriptase-2. Chem. Eur. J. 22, 85258535. (e) Cottam Jones, J. M., Harris, P. W., Scanlon, D. B., Forbes, B. E., Brimble, M. A., and Abell, A. D. (2016) Fluorescent IGF-II analogs for FRET-based investigations into the binding of IGF-II to the IGF-1R. Org. Biomol. Chem. 14, 2698-2705.

(35) Chang, C. L., Lien, E. J., and Tokes, Z. A. (1987) Synthesis, biological evaluation, and quantitative structure-activity relationship analysis of 2-hydroxy- $1 H$-isoindolediones as new cytostatic agents. J. Med. Chem. 30, 509-514.

(36) Clegg, R. M. (1995) Fluorescence resonance energy transfer. Curr. Opin. Biotechnol. 6, $103-110$.

(37a) Twumasi, D. Y., and Liener, I. E. (1977) Proteases from purulent sputum. Purification and properties of the elastase and chymotrypsin-like enzymes. J. Biol. Chem. 252, 1917-1926. 
(b) Green, B. G., Weston, H.; Ashe, B. M.; Doherty, J.; Finke, P.; Hagmann, W.; Lark, M.; Mao, J.; Maycock, A.; Moore, V.; Mumford, R.; Shah, S.; and Knight, W. N. (1991) PMN elastases: a comparison of the specificity of human isozymes and the enzyme from other species toward substrates and inhibitors. Arch. Biochem. Biophys. 286, 284-292. (c) Watorek, W., van Halbeek, H., and Travis, J. (1993) The isoforms of human neutrophil elastase and cathepsin G differ in their carbohydrate side chain structures. Biol. Chem. Seyler 374, 385-393. (d) Dau, T., Sarker, R. S., Yildirim, A. O., Eickelberg, O., and Jenne, D. E. (2015) Autoprocessing of neutrophil elastase near its active site reduces the efficiency of natural and synthetic elastase inhibitors. Nat. Commun. 6, 6722. 